Portland State University

PDXScholar

7-6-1994

\title{
The DNA Sequence Required for the Maximal Transactivation of the VP5 Gene of Herpes Simplex Virus Type 1
}

Shin Chen

Portland State University

Follow this and additional works at: https://pdxscholar.library.pdx.edu/open_access_etds

Part of the Biology Commons

Let us know how access to this document benefits you.

Recommended Citation

Chen, Shin, "The DNA Sequence Required for the Maximal Transactivation of the VP5 Gene of Herpes Simplex Virus Type 1" (1994). Dissertations and Theses. Paper 4716.

https://doi.org/10.15760/etd.6600

This Thesis is brought to you for free and open access. It has been accepted for inclusion in Dissertations and Theses by an authorized administrator of PDXScholar. Please contact us if we can make this document more accessible: pdxscholar@pdx.edu. 


\section{THESIS APPROVAL}

The abstract and thesis of Shin Chen for the Master of Science in Biology were presented July 6, 1994, and accepted by the thesis committee and the department.

COMMITTEE APPROVALS:

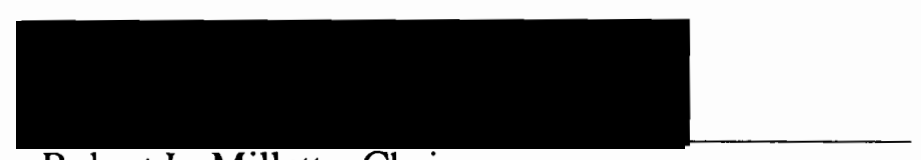

Robert L. Millette, Chair

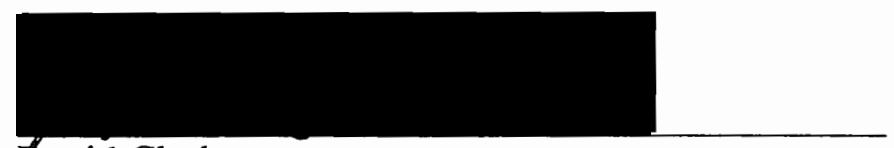

Bavid Clark

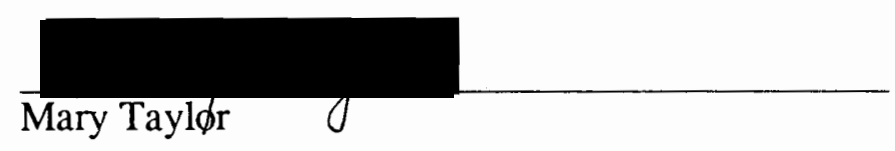

DEPARTMENT APPROVAL:

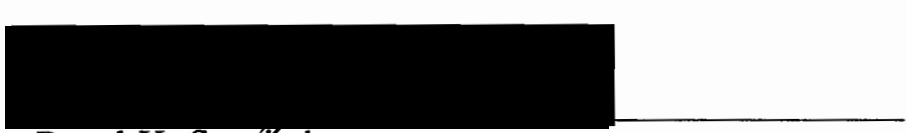

Pavel K. Smeytek

Representative of the Office of Graduate Studies

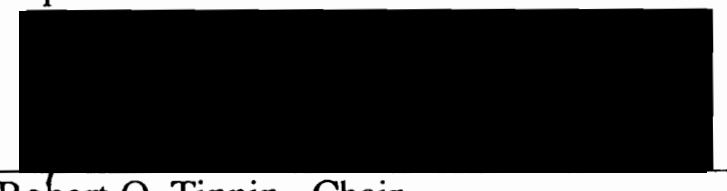

Robert O. Tinnin, Chair

Department of Biology

$* * * * * * * * * * * * * * * * * * * * * * * * * * * * * * * * * * * * * * * * * * * * * * * * * * * * * * * * * * * * * * * * * * * * * * * *$<smiles>[CH]1CCCC1</smiles>

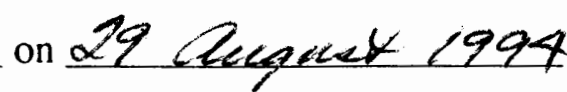




\section{ABSTRACT}

An abstract of the thesis of Shin chen for the Master of Science in Biology presented July 6, 1994.

Title: The DNA Sequence Required for the Maximal Transactivation of the VP5 Gene of Herpes Simplex Virus Type 1 .

A regulatory element involved in the transcriptional activation of the major capsid protein (VP5) of herpes simplex virus type 1 was identified and characterized in this research project. Gel mobility shift assay with nuclear extracts from both uninfected and HSV-1 infected Hela cells identified two major protein-DNA complexes involving the VP5 promoter. No viral specific complex found. DNase I and orthophenanthroline-Cu+ footprint analyses in the same laboratory revealed that the two complexes involve a single binding site, GGCCATCTTGAA, located between -64 and -75 bp relative to the VP5 cap site. To determine the function of this leaky-late binding site (LBS) in VP5 gene activation, mutated VP5 promoters with deletion and insertion around LBS were constructed and linked to a reporter gene, bacterial chloramphenicol 
acetyltransferase gene. The effect of mutations were tested in transient expression assay. Deletion of LBS resulted in seven to eight-fold reduction in the level of transactivation of the chloramphenicol acetyltransferase gene by superinfection with HSV-1 or by cotransfection of HSV immediate-early genes. These results indicated LBS is involved in the maximal transactivation of the VP5 gene. A search of published gene sequences found the homologs of LBS exist in a number of HSV-1 $\beta \gamma$ promoters, and other viral promoters, as well as cellar promoters. Some of these homologs have found involved in the transcription regulation. 
THE DNA SEQUENCE REQUIRED FOR THE MAXIMAL TRANSACTIVATION OF THE VP5 GENE OF HERPES SIMPLEX VIRUS TYPE 1

\author{
by \\ SHIN CHEN
}

A thesis submitted in partial fulfillment of the requirements for the degree of

\author{
MASTER OF SCIENCE \\ in \\ BIOLOGY
}

Portland State University

1994 


\section{ACKNOWLEGEMENTS}

My love to my family, who is always there to listen and provide moral support when I need it.

I would like to express my gratitude to my advisor, Dr. Robert L. Millette. His encouragement and support helped me make through this study.

Special thanks to my friend, Zhou-Ren Zhu, for everything he has done during those difficult days. 
TABLE OF CONTENTS

PAGE

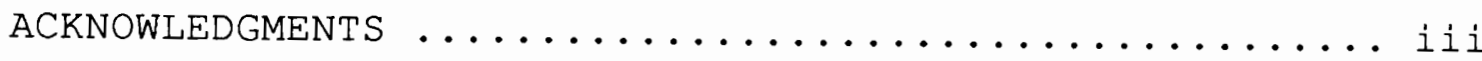

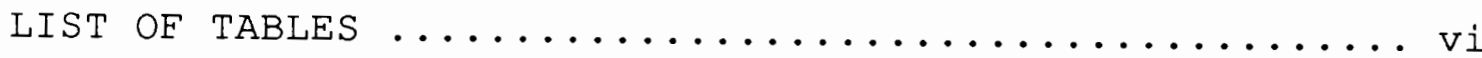
LIST OF FIGURES ...................... vii CHAPTER

I INTRODUCTION $\ldots \ldots \ldots \ldots \ldots \ldots \ldots \ldots$

General Background of $\mathrm{HSV} \ldots \ldots \ldots \ldots 2$

Viron Structure

HSV-1 Genome

Viral Replication

HSV-1 Gene Expression ............. 12

The Cascade of HSV-1 Gene Expression

Regulation of $\mathrm{HSV}-1$ Gene Expression

The Gene of Major Capsid Protein ...... 21

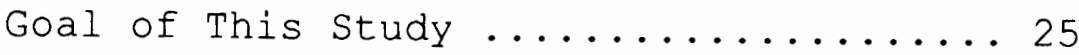

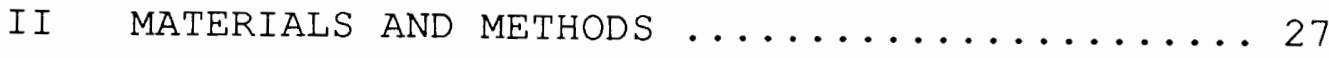

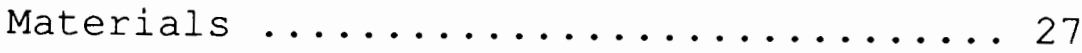

Preparation of DNA Probe ............... 31

Mobility Shift Assay ...............33

Competition Binding Assay ......... 34

Preparation of Mutated VP5 Promoter

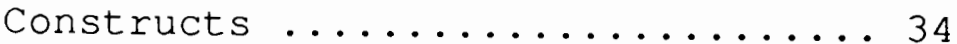

Transfection and CAT Assays ......... 41 
III $\operatorname{RESULTS} \ldots \ldots \ldots \ldots \ldots \ldots \ldots \ldots \ldots \ldots \ldots$

Two Protein-DNA Complexes Are Formed With the VP5 Promoter .........4 46

Analysis of Mutants ................ 54

Complex Eormation by the Mutated VP5 Promoters

The Promoter Activity in Transient Expression Assay 


\section{LIST OF TABLES}

TABLE

PAGE

1. The Promoters Tested in the Mobility

Shift Assay ..................4 49

2. Competition of VP5 promoter Complex

Formation by Viral and Cellular

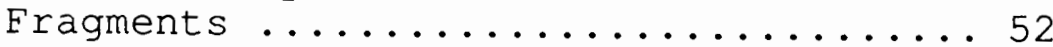

3. Promoter Sequences Homologous to the VP5

LBS Sequence ...................65 


\section{LIST OF EIGURES}

1. HSV Viron Structure .................. 5

2. Diagram of Herpesviruses Genome struction..... 7

3. Four Isomers of $\mathrm{HSV} \ldots \ldots \ldots \ldots \ldots \ldots \ldots$

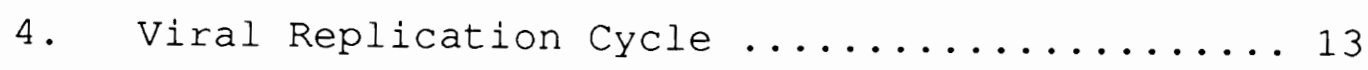

5. Cascade Regulation of HSV-1 Transcription .... 17

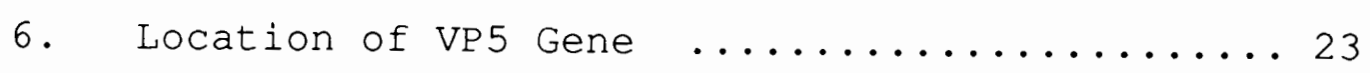

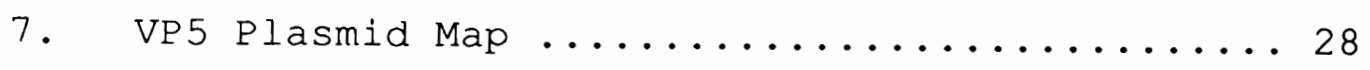

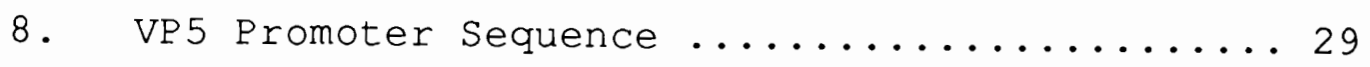

9. Strategy for Constrution of VP5 promoter

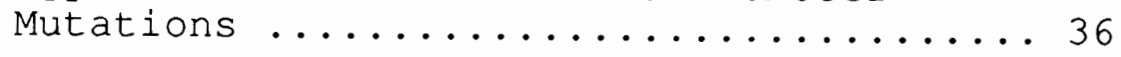

10. Diagram of Mutated VP5 promoters .......... 42

11. Gel Mobility Shift Analysis of the VP5

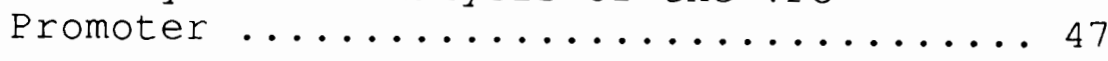

12. Competetion Binding of ${ }^{32} \mathrm{P}$ Labeled VP5

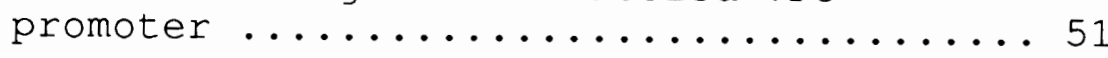

13. Diagram of VP5 promoter and Its subfragments - 53

14. Competetion Binding Assay of VP5 and Its Subfragments ..................... 55

15. Location of Complex $A$ and $B \ldots \ldots 6$

16. Mutated VP5 Promoters ............... 57

17. Competetion Assay of Mutated VP5 Promoters ... 59

18. Induction of VP5 Constructs by HSV-1

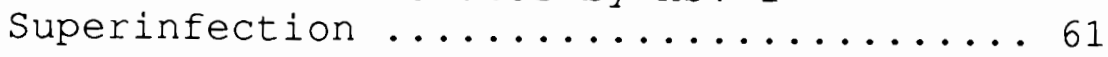

19. Induction of VP5 constructs bycotransfected

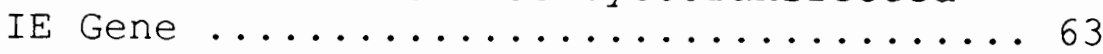




\section{CHAPTER I}

\section{INTRODUCTION}

The herpesvirus family, Herpesviridae, contains nearly 100 viruses that infect different eukaryotic species, from fungi to humans ${ }^{1}$. It was named for those members who are responsible for some common human diseases, the herpes simplex viruses. Herpesviruses also are found in other living organisms, e.g. B virus of monkeys (occasionally infect humans), pseudorabies virus of pigs, virus III of rabbits, and oncogenic viruses that produce lymphoproliferative malignancies in chickens and monkeys. Based on host range, replication features and latency, Herpesviridae is divided into three subfamilies: alphaherpesvirinae (includes the herpes simplex type 1 and 2 viruses and the varicella zoster virus), betaherpesvirinae (cytomegalovirus, human herpesviruse 6 and 7), gammaherpesvirinae, (EpsteinBarr virus). Within the subfamilies, viruses are further divided into genera based on DNA sequence homology, similarities in genome sequence arrangement, and relatedness of virion proteins as demonstrated by immunologic methods. Alphaherpesvirinae have a variable host range and short reproductive cycle. They spread rapidly in culture, efficiently destroy infected cells, and cause latent 
infections primary in sensory ganglia. Betaherpesvirinae have restricted host range. Their reproductive cycle is long, and their infection progresses slowly in culture. The virus can be latent in secretory glands, lymphoreticular cells, kidneys, and other tissues. The gammaherpesvirinae are specific for either $\mathrm{T}$ or $\mathrm{B}$ lymphocytes, and they frequently exist as latent viruses in lymphoid tissue.

\section{GENERAL BACKGROUND OF HSV}

Seven herpesviruses have been isolated from humans, herpes simplex virus type 1 (HSV-1) and herpes simplex virus type 2 (HSV-2), varicella zoster virus (VZV), human cytomegalovirus (HCMV), Epstein-barr virus (EBR), human herpesvirus 6 (HHV 6) and human herpesvirus 7 (HHV 7). Herpesviruses are very important for human beings. In America, over $87 \%$ of the population have been infected by one or more herpesviruses.

Herpes simplex viruses (HSV) were the first human herpesviruses to be discovered and are one of the most intensively investigated viruses. Herpes simplex viruses causes a wide variety of clinical infections, ranging from inapparent infection and focal cytopathogenicity to fatal encephalitis. An interesting feature of these viruses is their ability to establish a latent infection in neurons of the sensory ganglia, here they persist for the life time of 
the host, and they may periodically be reactivated to cause skin lesions and other disease symptoms.

As with many other known herpesviruses, HSV shares four significant biological properties:

1) HSV characteristically encodes a diverse array of enzymes involved in nucleic acid metabolism and DNA synthesis.

2) Both the synthesis of viral DNAs and the assembly of capsids occur in the nucleus.

3) Irreversible destruction of the infected cell is the consequence of infectious progeny virus production.

4) The viruses are able to become latent in neurons. In some cases, the latent viral genomes take the form of closed circular molecules and only one viral gene region is expressed ${ }^{2}$.

Herpes simplex viruses type 1 and type 2 can be distinguished by neutralization titration and by their distinct clinical patterns. Both types show cross reactivity antigenically and share approximately $50 \%$ homology in their genomes. They differ in restriction endonuclease cleavage sites and in the apparent sizes of viral proteins. Herpes simplex viruses exhibit focal cytopathogenicity. The type 1 virus is primarily associated with oral and ocular lesions and is transmitted by oral and respiratory secretions, whereas type 2 is isolated primarily from genital and anal lesions and is generally passed through sexual contact. 
Fever blisters or cold sores are the common diseases that result from HSV-1 infection. The more severe infection may cause 1) disseminated disease to visceral organs, 2) severe deep ocular involvement which can lead to blindness, or 3) herpes encephalitis. $\mathrm{HSV}-2$ is the causative agent for herpes genitalis and generalized herpes of newborn. It is also frequently associated with cervical carcinoma. For example, HSV-2 has been isolated from 85\% of the cervical carcinoma patients. HSV-1 usually establishes latent infection in neurons of the trigeminal ganglia, whereas HSV-2 generally become latent in sacral ganglia.

\section{Virion structure}

Herpes simplex type 1 is an enveloped virus of about $150 \mathrm{~nm}$ on diameter (Fig. 1). As with all herpes virons, the HSV-1 virion consists of four elements: (1) an electron dense core, (2) an icosadeltahedral capsid surrounding the core, (3) an amorphous tegument surrounding the capsid, and (4) an outer envelope containing many viral glycoprotein spikes on its surface. The electron dense core is about $75 \mathrm{~nm}$ in diameter, and it contains the linear, double-stranded DNA genome of the virus. The structural features of the capsid, 95 to $100 \mathrm{~nm}$ in diameter and comprised of 162 capsomeres, are characteristic of all the herpesviruses. The capsid is composed of a number of viral proteins, at least eight of which have been identified: VP5, VP19, VP21, VP22, VP22a, 


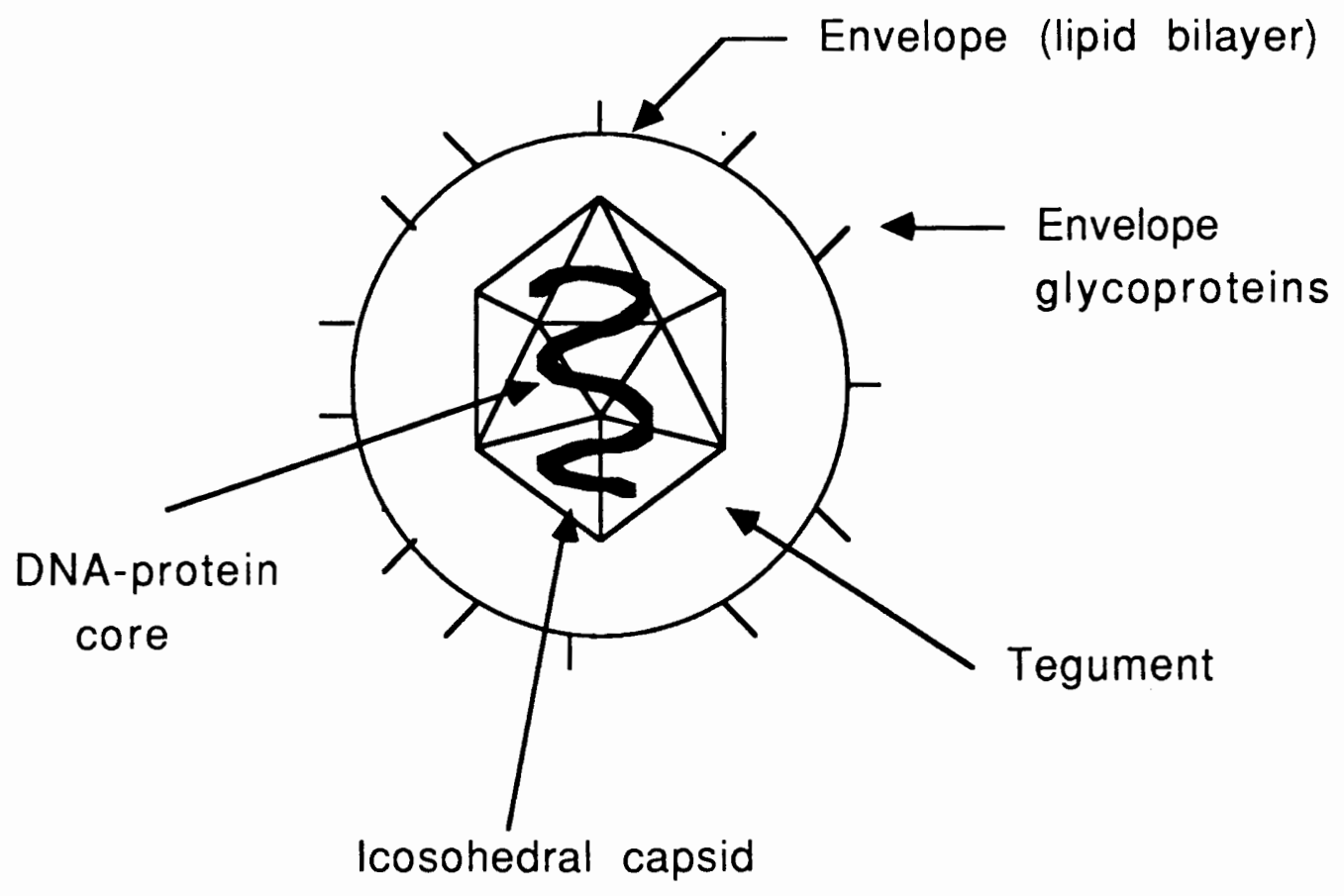

FIG. 1. Diagram of a virion of Herpes simplex virus. 
VP23, VP24, and $12 \mathrm{kd}$ protein. The tegument, the granular zone surround the capsid, contains the virion host shut-off (vhs) protein, the $\alpha$-trans-inducing factor (variously described as $\alpha-T I F$, ICP25, or VP16, a protein required for activating immediate-early gene transcription), immediateearly proteins ICP4 and ICPO, and a very large protein (VP1) associated with a complex that binds to the terminal "a" sequence of the viral genome 3,4 . The envelope is derived from the inner membrane of the host cell nucleus modified by the insertion of viral glycoproteins. These glycoproteins are gB, gC, gD, gE, gG, gH, gI, gJ, gK, gL and gM. Three of them ( $g B, g D$, and $g H)$ are clearly indispensable for viral replication, the rest of them are dispensable in cell culture for both entering into cell and releasing from cell5, 6 .

\section{HSV-1 Genome}

The genome of HSV-1 consists of one Iinear doublestranded DNA of 152 kilobasepairs with a molecular weight of $100 \times 10^{6}$ daltons. It is composed of two regions, a long region (L) and short region (S) which comprise $82 \%$ and $18 \%$ of the viral DNA, respectively (Figure 2). Each of these regions consists of unique sequences bracketed by inverted repeat sequences. The repeats of long region are designated ab and b'a', whereas the repeats of the short region are designated $a^{\prime} c$ ' and $c a$. The number of a sequence repeats at the L-S junction and at the termini is variable. 

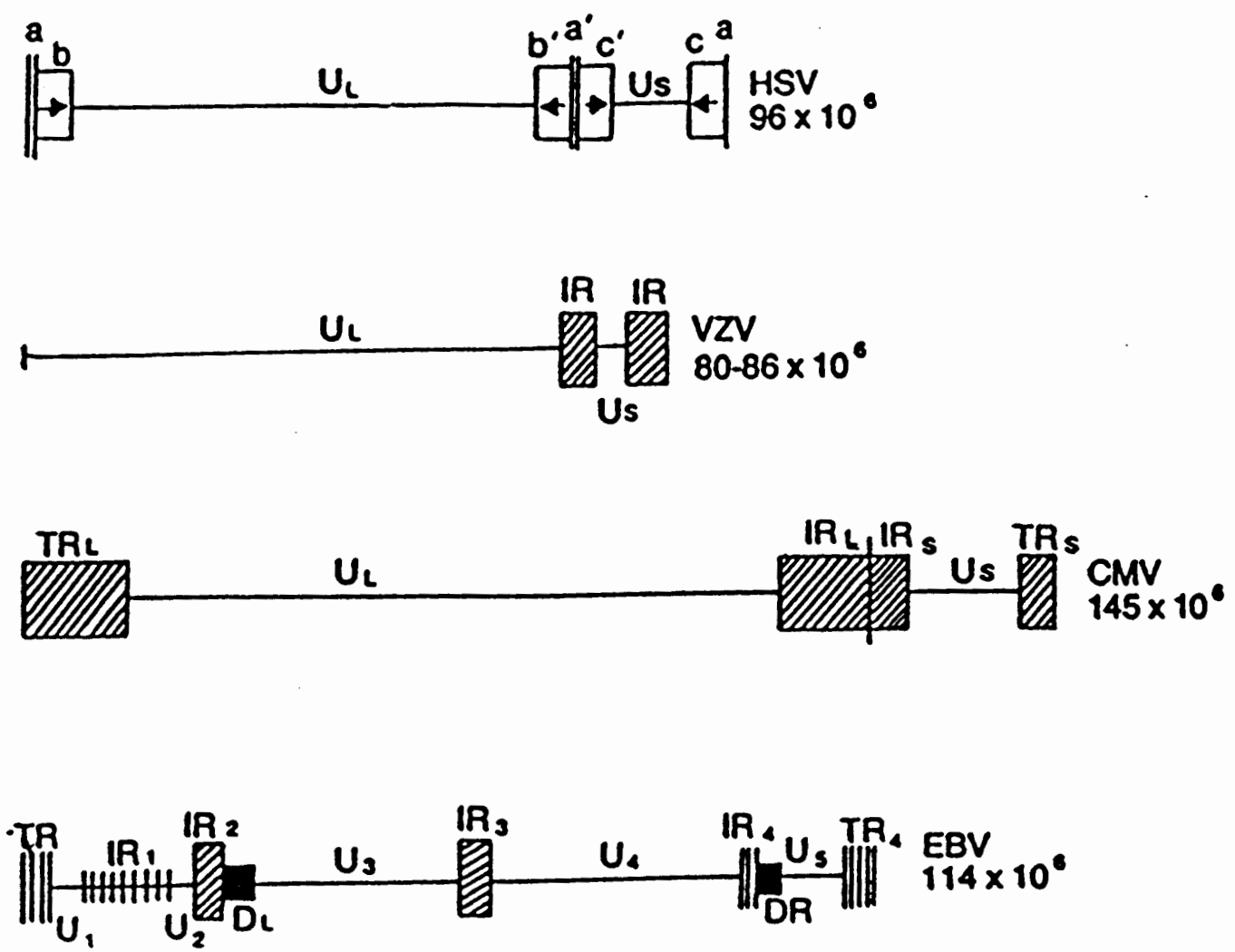

EIG. 2. Diagrams of the physical structures of genomes of several viruses of the family Herpesviridae. The genomes are composed of unique long ( $U_{L}$ ) and unique short (US) region. Terminal repeats (TR) bound the genome, and inverted repeats (IR) bound the unique regions. (Dulbecco. 1988) 
The HSV-1 a sequence is approximately $85 \% \mathrm{G}+\mathrm{C}$ and 200 to $500 \mathrm{bp}$ in length. It contains $20 \mathrm{bp}$ direct repeats on each end and two unique segments separated by internal directly repeated regions. The structure of the terminally repeated a sequence is highly conserved but contains a variable number of internal repeat elements. The size of the a sequence also varies from strain to strain. The a sequence is involved not only on recombination, but also in processing and packaging the viral DNA.

During the replication, recombination occurs through the inverted repeats of a sequence and gives rise to different isomeric forms of the genome, and recombination is closely associated with viral DNA replication? The ability to exist as four linear isomers which differ in the relative orientations of the long region and short region is a property of herpes simplex virus shared, in part, with several other herpesviruses (Figure 3). Viral DNA prepared from purified virion consists of four isomers present in equal molar amounts. These isomers have been designated as $P$ (prototype), $I_{L}$ (inversion of the L region), $I_{S}$ (inversion of the $S$ region), ILS (inversion of both $S$ and $L$ regions). The a sequence and viral trans-acting factors are required for inversion. The physiologic function of the inversion of $L$ and $S$ regions is not clear. However, a HSV-1 mutant that is locked in one orientation is perfectly viable 8 . 
A.

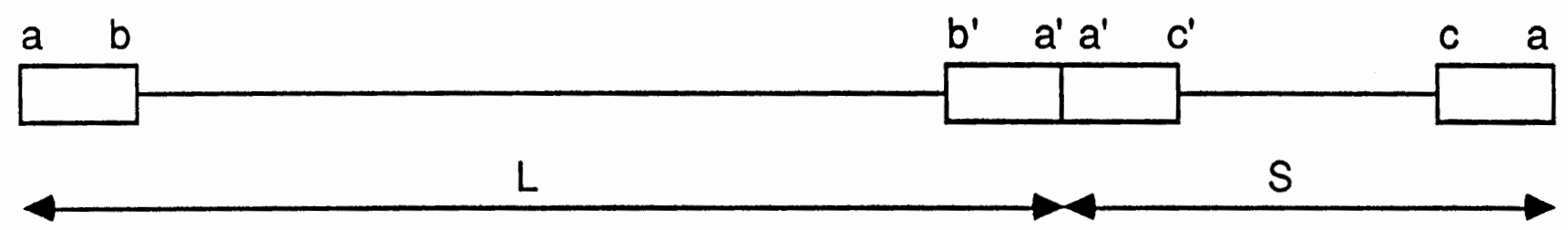

B.
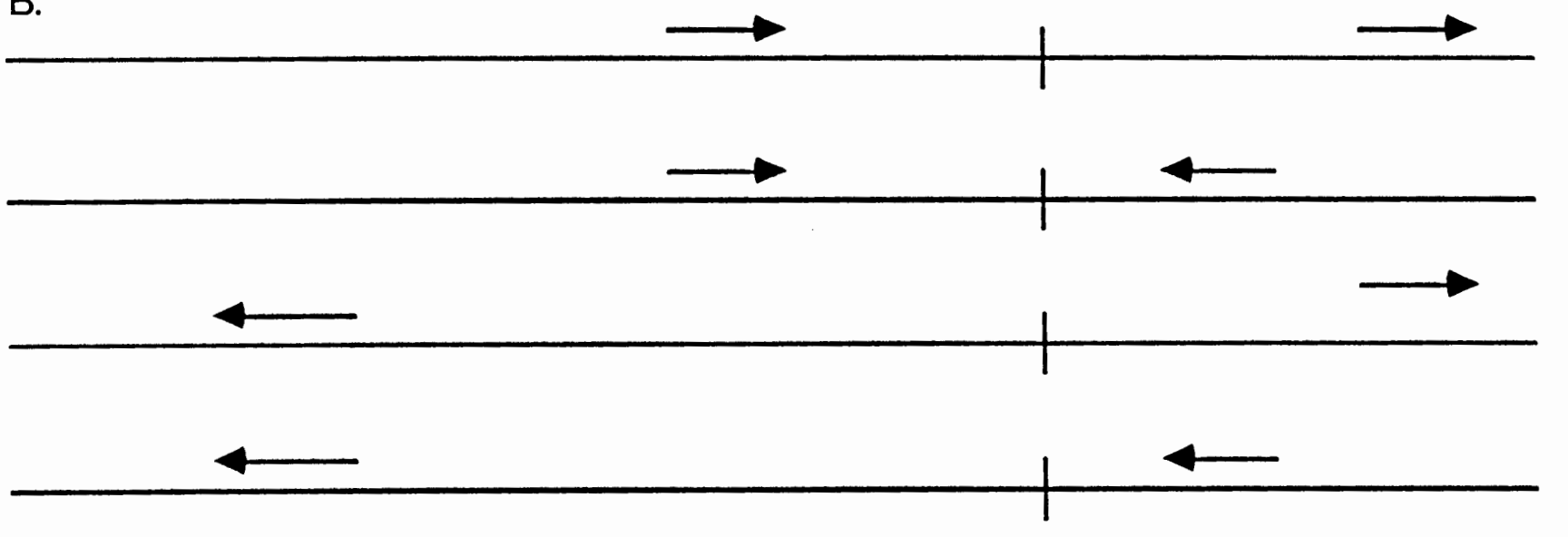

FIG. 3. Schematic representation of the arrangement of DNA sequences in the HSV genome. A. The domins of the $L$ and $S$ components are denoted by the arrows. B. The four isomers of the HSV DNA. 
Viral Replication

HSV-1 viruses have a rather wide host range of both in vitro and in vivo. Infection start with attachment which is mediated by the binding of viral glycoproteins to heparan sulfate moieties of cell surface, and enzymatically removal of heparan sulfate from cell greatly reduced the level of attachment and infection of those cell 9 . Spear and colleagues also showed that either glycoprotein gB or gC is required for attachment. Although $\mathrm{gC}$ is dispensable for replication of $\mathrm{HSV}$ in cell culture, it facilitates virion adsorption to cells and enhances infectivity by about a factor of 1010 . The attachment activates a penetration process mediated by viral surface proteins which cause the fusion of the viral envelope with the cell plasma membrane. Glycoproteins $g B, g D$ and $g H$ are indispensable for the fusion of the viral envelope and cell membrane $11,12,13$.

After penetration, the viral nucleocapsid is transported along the cytoskeleton from the site of entry to nuclear pores. There the viral DNA and is released into the nucleus. There are virion components protect and facilitate the entry of the DNA into cells, and also appear to be involved in the early shut off of host macromolecular synthesis. The linear, double-stranded viral DNA circularizes immediately upon release from capsid. Once in the nucleus, the viral DNA is transcribed by host RNA polymerase II with the participation of various viral and cellular factors. HSV 
mRNAs are capped, methylated, and polyadenylated, and only small proportion of viral mRNAs are derived by splicing. The abundance and stability of the various HSV-1 mRNAs appear to vary.

Viral DNA synthesis is carried out by viral proteins and host cell enzymes in nucleus. There are three origins of DNA replication: two in the terminal repeat sequences of short region, between the promoters of ICP4 and ICP22(ori 1) or ICP4 and ICP27(ori 2), and onelori 3) in the middle of the unique long region between the genes encoding the DNA polymerase and the DNA binding protein (ICP8) ${ }^{14}$. By transfecting cells with a plasmid containing an origin of DNA synthesis and various fragments of the HSV genome, genetic studies have shown that seven genes are essential for HSV origin-dependent DNA replication: UL9 encodes an origin recognition protein 15 ; UL5, UL8, and UL52 encode the three subunites of a helicase-primase complex ${ }^{16}$; UL29 encodes a single-strand DNA binding protein ICP817; UL30 encodes a DNA polymerase 18 ; and UL42 encodes a double-strand DNA binding protein that is a subunit of DNA polymerase ${ }^{19}$.

The translation of viral mRNAs occurs in the cytoplasma on both bound and free polyribsomes. Most of the proteins seem to be processed extensively. Processing includes cleavage, phosphorylation, sulfation, glycosylation poly(ADPribosyl)ation, and nucleotidylylation. Structural proteins 
and most regulatory proteins are transported into the nucleus where new capsid assembly occurs.

The concatemeric viral DNA synthesized by a rolling circle mechanism is cleaved at terminal repeats in the a sequence and packaged in preformed capsid. These particles are unstable and noninfectious until they acquire envelope. Unlike other enveloped virus, the envelopment occurs at the inner lamella of the nuclear membrane which has been modified by viral glycoproteins. The release of virus does not occur by budding from plasma membrane, rather through the cisternae of the endoplasmic reticulum which extend to the plasma membrane (see Figure 4)

\section{HSV-1 GENE EXPRESSION}

The cascade of HSV-1 gene expression

The DNA sequence of the 152-kilobase genome of herpes simplex virus type-1 (HSV-1) has been determined. It encodes at least 72 unique proteins 20,21. Fifty six of the open reading frames are in $U_{L}$ region, twelve are in $U_{S}$ and one each in the repeat regions. Although the function of many of these genes has been determined, there are still many whose function in either viral replication or viral pathogenicity is not known. The transcription of viral DNA takes place in the nucleus by host RNA polymerase II and all viral proteins are synthesized in the cytoplasm. During the productive infection, the synthesis of these proteins is temporally and 


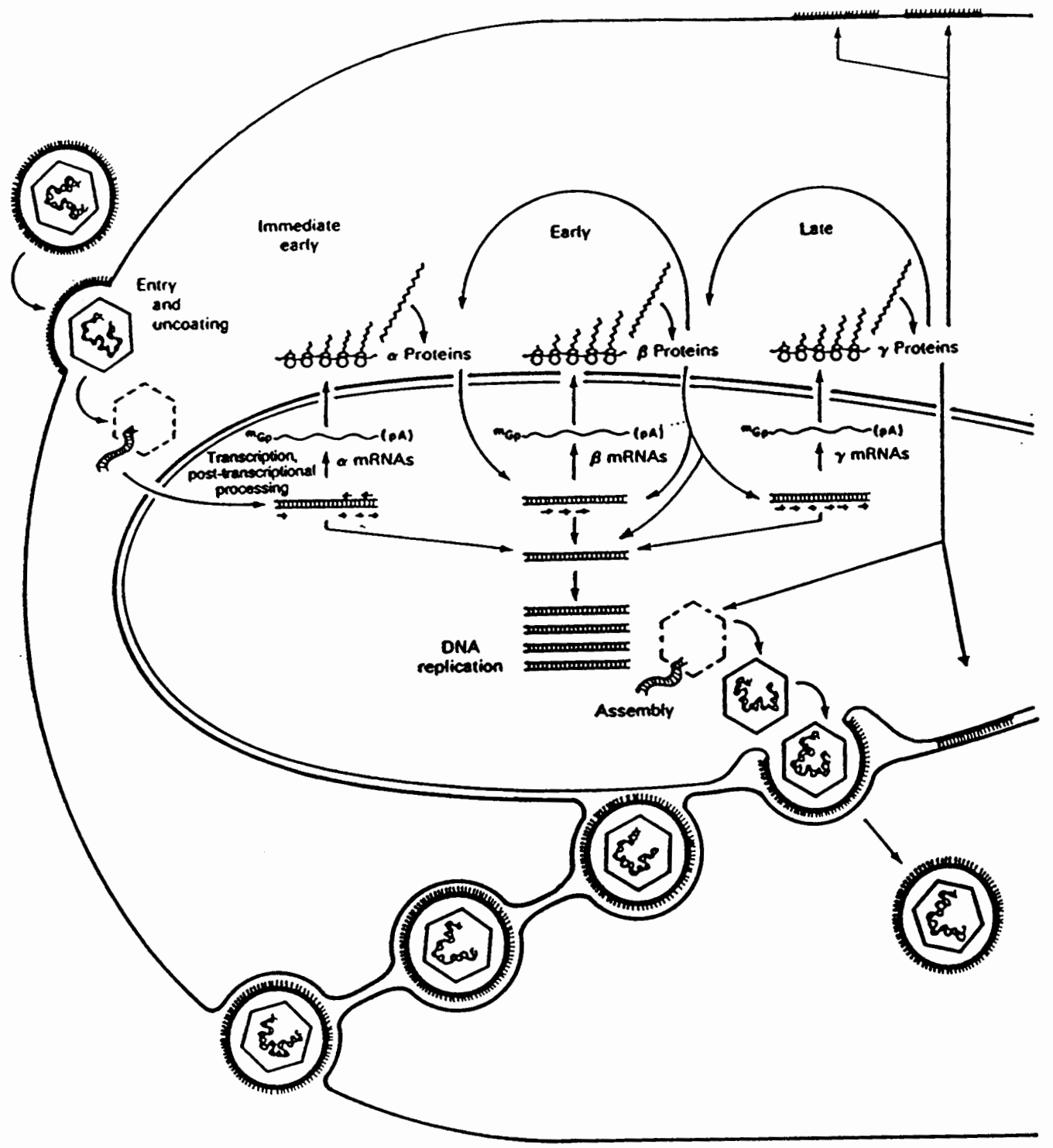

FIG. 4. Sequence of events in the multiplication of herpes simplex virus from entry of the virus into the cell by fusion of the virion envelope with the host membrane to assembly of virions and their exit from the cell through the endoplasmic reticulum. (Dulbecco 1988) 
quantitatively regulated, primarily at the transcriptional level by cis-acting signals within the viral genome and trans-acting factors encoded in both the host and viral genomes 22,23 . Based on this cascade fashion of gene expression, the viral genes were classified into three kinetic classes which were designated as immediate-early (alpha), early (beta), late (gamma)24, 25.

Alpha genes are those that are expressed in the absence of viral protein synthesis. The synthesis of $\alpha$ polypeptides reaches maximal rates at approximately 2 to 4 hours postinfection and they accumulate until late in infection. HSV-1 encodes four $\alpha$ proteins which have been shown to affect the expression of HSV-1 genes, namely, infected cell polypeptides ICP0 (IE110), ICP4 (IE175), ICP22 (IE68), and ICP27 (IE63). The function of the fifth $\alpha$ protein, ICP47 (IE12), has not been established, but does not appear to affect HSV-1 gene expression in tissue culture 26 . In addition to the five $\alpha$ genes, the latency-associated transcript 1 (LAT1) and a transcript designated as Oris RNA are transcribed under $\alpha$ conditions(i.e. in the absent of protein synthesis).

Beta genes are not expressed in the absence of $\alpha$ proteins and their expression is enhanced in the presence of inhibitors of viral DNA synthesis. The $\beta$ transcripts can be detected 2 hours postinfection. Their synthesis reaches maximal rate following the initiation of DNA replication, about 5 to 6 hours post-infection and gradually decrease to 
nearly undetectable levels late in infection. Subgroup $\beta 1$, that includes ICP6 (ribonucleotide reductase) and ICP8 (the major DNA-binding protein), are expressed earlier than subgroup $\beta 2$ which includes ICP36 (viral thymidine kinase) and HSV DNA polymerase. The $\beta$ genes primarily encode products required for DNA synthesis, and the appearance of their products signal the onset of viral DNA synthesis (about 2 to 3 hours post-infection).

The expression of late genes require the prior $\alpha$ and $\beta$ gene expression. Late genes specify virion structural proteins and have been divided into two subgroups, $\beta \gamma$ (or $\gamma 1$ ) and $\gamma($ or $\gamma 2)$, based on the sensitivity of their expression to DNA inhibitors. Low level of $\beta \gamma$ genes ( $g B, g D$ and VP5) transcripts are detectable prior to viral DNA synthesis, whereas essentially no $\gamma$ gene (e.g. gC, US1l and UL38) transcription is observed. Following the initiation of viral DNA replication, 2 to 3 hours post-infection, both $\beta \gamma$ and $\gamma$ expression increase and reach peak level at 7 to 8 hour postinfection and remain at high level late in infection.

\section{Regulation of HSV-1 gene expression}

The regulation of HSV-1 gene expression has become a major focus of research, and the mechanism by which the virus regulates its replication remains an exciting area of investigation. 
The expressions of $\alpha$ genes are induced by $\alpha-$ TIF (Vmw65 or VP16), which is a virion phosphoprotein synthesized late of infection and incorporated into tegument during virion assembly. When $\alpha$-TIF is released into infected cell, it induces viral immediate-early gene expression via two cis-acting elements, the TAATGARAT and GCGGAA consensus sequences present in the IE promoters 27 ( see figure 5). Alpha-TIF does not bind to DNA itself, but it forms a complex with cellular transcriptional factor oct-1 (NFIII, OTF-1), and Oct-1 directly bind to the consensus sequences of IE promoters. Kristie and Sharp demostrated that at very high concentration, $\alpha-T I F$ could form complexes with DNA in the absence of oct-128. This function is dispensable in tissues culture at high multiplicity, but is required for normal virus replication at low multiplicity of infection. Therefore, the IE gene expression is not totally dependent on the activity of $\alpha-$ TIF.

All immediate-early proteins except ICP47 are nuclear phosphoproteins, and they regulate their own synthesis as well as the protein synthesis of other kinetic classes. Studies using viral ICP4 gene mutant have shown that ICP4 is involved in autoregulation of its own expression as well as that of other $\alpha$ genes, and it activates of $\beta, \beta \gamma$, and $\gamma$ expression29, 30. Transcription of $\beta$ (ICP8), $\beta \gamma$ (ICP5, gB), and $\gamma(\mathrm{gC})$ genes is dependent on ICP431, 32. ICP4 represses expression from its own promoter and the ICPO promoter by 


\section{CASCADE REGULATION OF HSV-1 TRANSCRIPTION}

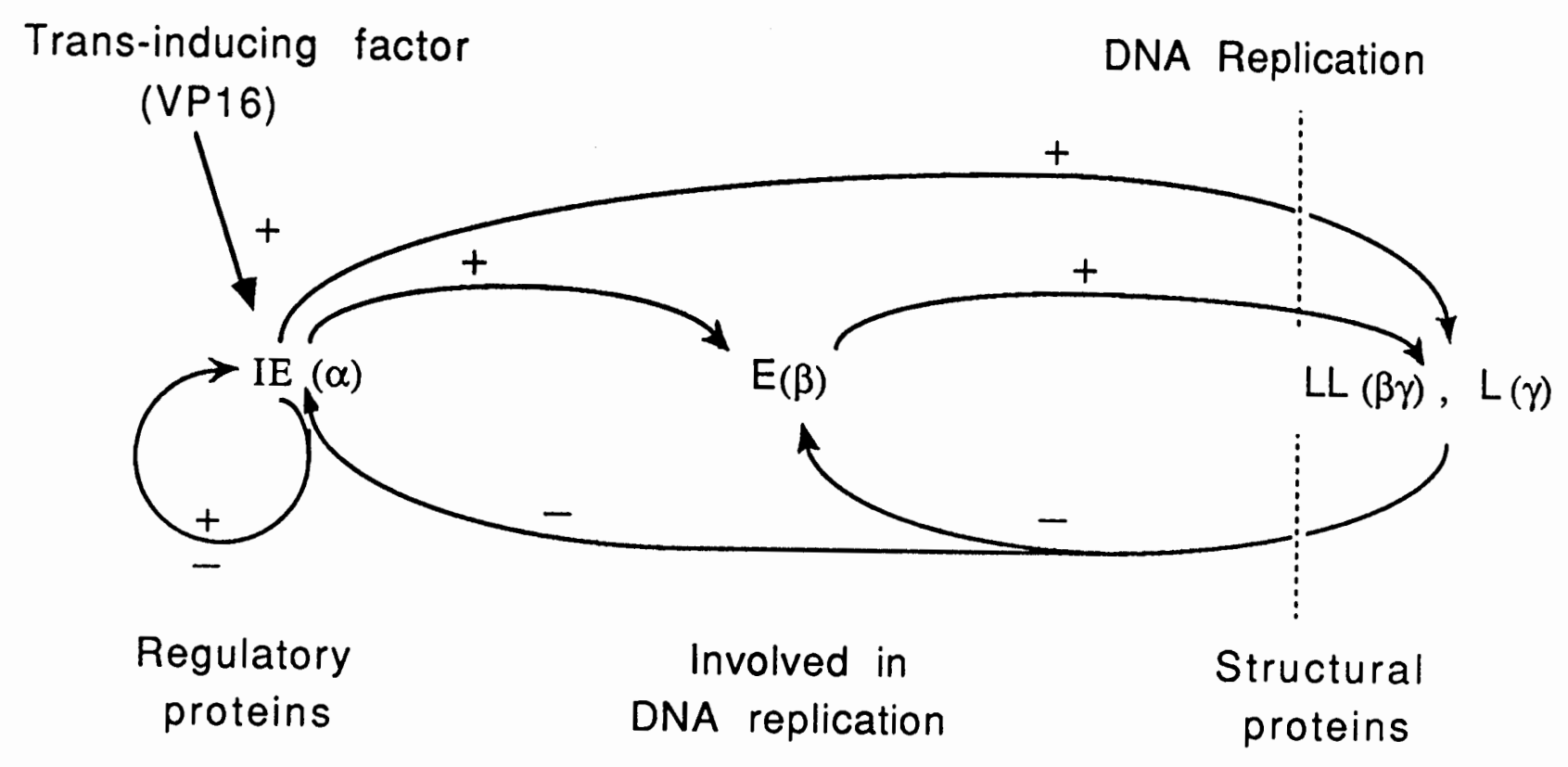

FIG. 5. Diagram of the cascade regulation of HSV-1 transcription. 
binding to a specific sequence, ATCGTC, near the transcriptional start site 33, 34, 35. Mutations which eliminated DNA binding of ICP4 also eliminated or reduced both ICP 4 transactivation and autoregulation indicating that DNA binding of ICP4 is required for these functions 36 . Studies have shown that HSV-1 infected cells that expressed defective ICP4 failed to: 1) activate the transcription of early and late genes, 2) induce viral DNA synthesis, and 3) down regulate immediately-early gene expression ${ }^{37}$. The HSV-1 tk, a $\beta$ gene is efficiently expressed only in the presence of IE gene products ${ }^{38}$. Faber and Wilcox's studies have attempted to define the tk promoter domains required for ICP4 induced expression. None of the tk sequences that interact with ICP 4 contains a consensus binding site for ICP4. This result suggest the ability of ICP4 to interact with more than one DNA sequence.

ICP 27 is an essential gene which has both activator and repressor functions. In the absent of functional ICP27, $\alpha$ genes are overexpressed, whereas the viral DNA replication reduced and late genes poorly expressed. In transient assay, ICP27 appears to have Iittle or less effect alone on most HSV-1 promoters, but has two different effects on combination with ICPO and ICP4, depending on the target genes. A strong repression was observed in transfection of immediate-early (ICP0, ICP27), early (TK), and leaky-late (gB, gD) and late (gC) promoters with these three IE, whereas increased 
transactivation were shown with a early promoter (alkaline exonuclease) and a leaky-late promoter (VP5)39, 40. Analysis of the mutant phenotypes demonstrated the genetic evidence for these two distinct transactivation functions of ICP2741, 42. Cells infected with deletion mutants of ICP27 synthesize viral DNA, but late genes $(\gamma)$ are not expressed43. SandriGoldin, et al. recent study showed the major effect of ICP27 appears to be at post-transcriptional level 44 .

In contract to ICP 4 and ICP 27 which were absolutely essential for virus replication, ICPO deletion mutant grow as well as wild-type virus and produce same amount of viral proteins at high multiplicities of infection, but grow poorly and produce a less amount viral proteins at low multiplicities. Therefore, ICPO is important but not essential in viral production cycle. Transient expression assays have shown that ICPO is a strong trans-activator of all classes of viral HSV-1 genes as well as a number of cellular genes. The mechanism by which ICPO transactivates viral and eukaryotic promoters is unclear. Available evidence shows that ICPO activates many promoters although it does not appear to require any cis-acting element for this activity 45 . ICPO and ICP 4 can stimulate expression of HSV-1 early and late promoters synergistically, since increased levels of induction have been observed when both are present than with either one alone 46,47 . 
There is no evidence indicating that ICP 22 or ICP 47 affect viral gene expression in transient expression assay, although in certain cell types ICP22 is essential for efficient viral replication and late gene expression 48 .

The $\beta$ genes are under the control of promoters that are active at low levels in uninfected cells or high levels in infected cells. The $\beta$ promoters are activated by ICP 4 and ICP0, or can be stimulated by exogenous enhancers (e.g. simian virus 40)49. Most of $\beta$ gene products are proteins involved in viral DNA synthesis, and may have both positive and negative regulatory functions. Godowski and knipe have suggested that in addition to its DNA binding function, ICP 8 may be important, also, in the maintenance of the highly ordered cascade of viral gene expression since defects in the ICP 8 protein result in increased mRNA level of $\alpha$ (ICP4), $\beta$ $($ ICP 8$), \beta \gamma(I C P 5)$ and $\gamma(g C) . \quad$ ICP 8 is required for shut-off of transcription of ICP4 and decrease in the transcription of $\beta, \beta \gamma$ genes.

The promoter structure of late genes is least understood and highly varied. Late genes do not appear to be efficient-ly expressed in uninfected cells. Temperature sensitive mutants studies have shown that ICPO, ICP4 and ICP27 are essential for efficient expression of late promoters. Except for an ICP4 binding site in the gD promoter50, extensive mutational analyses have not uncovered cis-acting sequences in leaky late promoters that are 
specifically required for activation by IE proteins. The TATA element is the only consensus sequence identified in the upstream regulatory region of true late promoters 51.

Deletion studies have indicated that little upstream sequence from TATA element is required for efficient expression of true late genes, but sequences downstream from the TATA element are important even though no consensus sequence have been identified 52 . Homa et al. suggested that true late promoter activity requires a specific type of TATA element, since tk TATA box was unable to function when it was moved to the gC locus. The inhibition of viral DNA replication causes a moderate reduction in the accumulation of $\beta \gamma$ mRNAs and a strong reduction of the accumulation of $\gamma$ mRNAs 53 .

\section{THE GENE OF MAJOR CAPSID PROTEIN}

The architecture of capsid is one of the characteristic features of the herpesvirus family. Capsid consists of 150 hexavalent capsomers which form the edges and faces of the icosahedron and 12 pentavalent capsomers that are located at the capsid vertices. There are three distinct types of capsids that can be isolated from the nuclei of herpesvirus infected cells. Type $A$ are the capsids that lack DNA and are never enveloped; type B contains DNA but are never enveloped; type $\mathrm{C}$ contains DNA and are obtained by de-enveloping intact virus. Empty capsids consist of five proteins, VP5, VP19C, VP23, VP24, and a small protein ${ }^{54} ;$ type $B$ capsid contains two 
additional proteins, VP21 and VP22a; instead of VP22a, type C capsid contains VP22.

The major capsid protein (VP5) constitutes

approximately $60 \%$ of the total capsid $B$ mass and is

considered to be the basic component of the hexavalent capsomers. In 1979, Anderson et al. reported that a $6 \mathrm{~Kb}$ mRNA was the most abundant viral transcript associated with polyribosome late in infection. In 1981, Costa et al. mapped this $6 \mathrm{~Kb}$ mRNA between 0.23 and 0.27 map units of the viral genome (Figure 6). In 1984, this $6 \mathrm{~kb}$ mRNA was able to be translated in vitro into a protein with molecular weight of 155,000. By using a polyclonal antibody made against purified HSV-1 VP5, Costa et al. confirmed the product of 6 Kb mRNA was the major capsid protein VP 5.

The gene encoding VP5 belongs to leaky-late or $\beta \gamma$ class. Like true late genes, the promoter structure of leaky-late genes and the requirements of leaky-late gene expression remain mostly mystery. Despite the requirement of DNA replication for maximal expression, the VP5 promoter has all the features of a typical eucaryotic transcriptional promoter, and it has served as a good model for the $\beta \gamma$ class genes. VP5 promoter is inactive in uninfected cell. In a transient assay using a reporter plasmid, the VP5 promoter was not active in uninfected cells55. In addition, a Hela cell nuclear transcription extract did not initiate transcription of VP5 under the conditions in which $\beta$ gene 


\section{LOCATION OF VP5 IN HSV-1 GENOME}

(a)

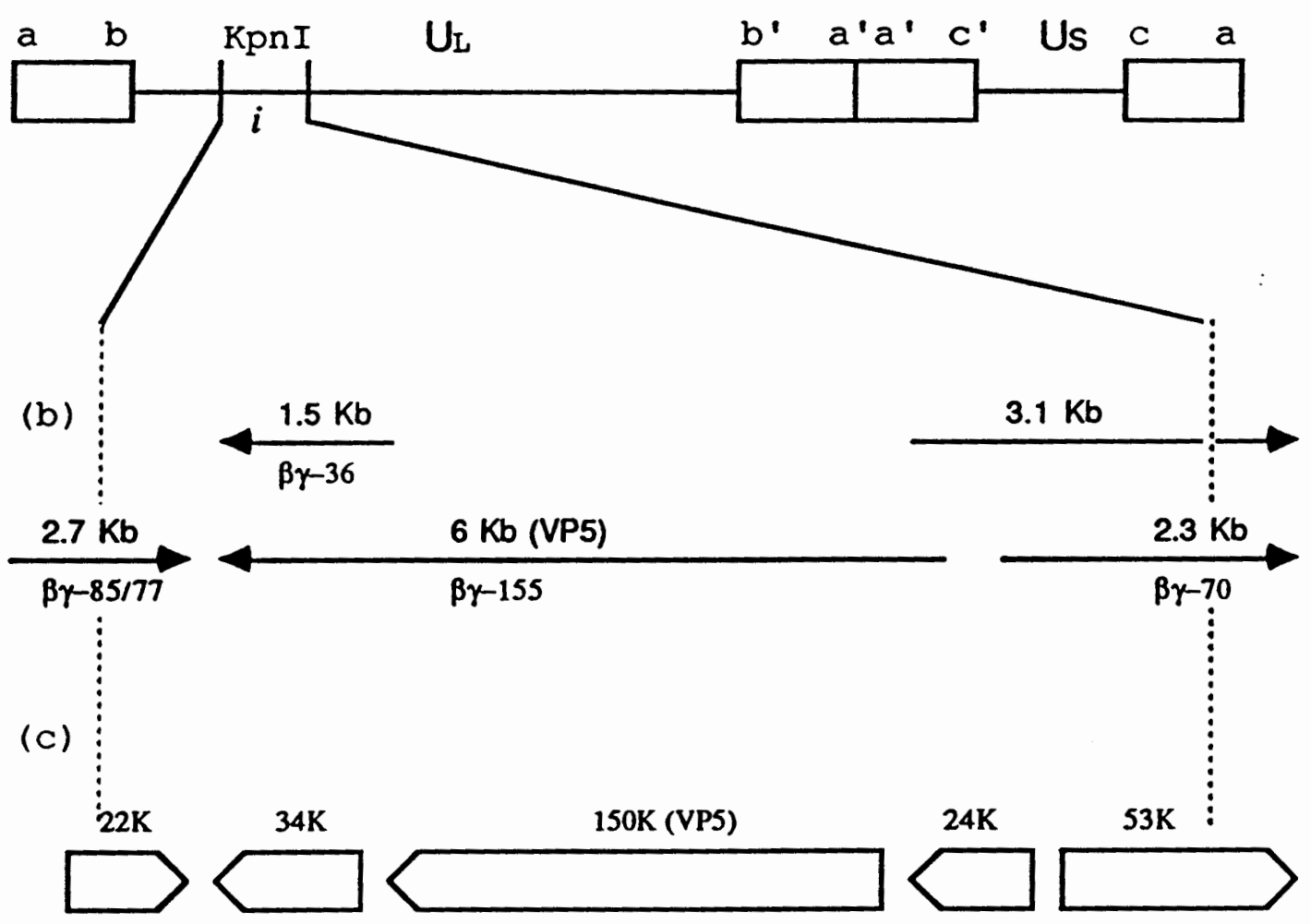

EIG. 6. (a) Location of Kpn I i fragment in the HSV-1 genome (Preston et al., 1978). (b) Location of VP5 mRNA in Kpn I i fragment. The size of the mRNA are indicated above the transcripts. The kinetic class and apparent molecular weights $\left(\times 10^{3}\right)$ of in vitro translation products are indicated below the transcripts. (c) Location of protein coding regions in Kpn $I$. Each open reading frame is shown as an open arrow. The approximate molecular weights of encoded proteins are indicated. 
transcription was initiated. However, a VP5 promoter was readily transactivated in transient expression assay either by HSV super-infection or $\alpha$ gene ICPO, ICP 4, and ICP 27 cotransfection 56, 57. The level of activation of VP5 promoter was directly proportional to the level of ICP 4 expressed in the cell 1 ine 58 . In addition to IE proteins, studies using inhibitors of viral DNA synthesis have shown that the viral. DNA replication was also required for VP5 maximum expression. But the mechanism of this coupling is unclear.

Detailed studies of the expression of a reporter gene under the control of various length VP5 promoters in transient expression assays showed that 75 bp upstream sequence of VP5 promoter was active at low levels in uninfected cells, and it was sufficient to allow higher expression with HSV super-infection even though the expression level was lower than the maximum level driven by $125 \mathrm{bp}$ of upstream sequence of the VP5 promoter. DNA sequence between -75 to -125 relative to the cap site repressed the activity of VP5 promoter in uninfected cells, but it was required for maximum level of transactivation by superinfecting virus or by cotransfected IE genes ${ }^{39}$. R. H. Costa and E. K. Wagner suggested that all the modification of host cell's transcriptional machinery required for maximum expression of the VP5 gene is accomplished by IE or E gene products or both, since inhibition of viral DNA synthesis 
increased CAT gene expression driven by VP5 promoter in infected cells.

GOAL OF THIS STUDY

One of the major goal of herpes virus studies is to prevent not only the primary infection but also the recurrent infection. To achieve this goal, it is necessary to understand the molecular biology and pathogenesis of HSV infection. Studies of HSV gene regulation provides a major step towards this understanding. The regulatory mechanisms of late gene expression are less well characterized than those of immediately early genes and early genes. VP5 promoter contains all the features of a typical eucaryotic transcriptional promoter. It is a good model for a leakylate gene in which the interaction of viral and cellular transcriptional factors and viral DNA control sequences can be studied.

In the early studies of VP5 promoter by other laboratories, viral IE proteins, ICP0, ICP4, ICP27, were found to be required for transactivation. But exactly how the three IE proteins transactivated VP5 promoter, what cisacting sequence required, and if any cellular transcriptional factor(s) involved are unknown. By using mobility shift, competition binding assay, deletion mutant analysis and transient expression assays, I have carried out a series of studies to characterize and determine the function of viral 
and cellular factors, and the DNA sequences involved in the regulation of HSV-1 leaky late gene expression. These are the questions I have asked in this research project:

1) How do the HSV-1 Immediately-early proteins ICPO, ICP4, and ICP27 transactivate the VP5 promoter? Is there any DNA sequence in the promoter that directly binds to viral protein(s)? Can any of the three protein be dispensed?

2) Is there any cellular factor(s) involved in the transactivation? Are there specific HSV-1 VP5 promoter sequences involved? How important is this DNA sequence in affecting the VP5 promoter activity in both uninfected cells and HSV-1 infected cells?

3) Is there any homology between the VP5 binding site identified and other HSV $\beta \gamma$ gene promoter sequences? Do they form the same or similar protein complexes?

4) Do homologous or similar regulatory DNA sequence exist in other viruses? Is the same, or similar, cellular factor associated with them? What do we know about the function of this cellular factor? 
CHAPTER II

\section{MATERIALS AND METHODS}

\section{MATERIALS}

\section{Plasmids}

pVP5 $(-4 /-168)$ CAT, pVP5 $(-4 /-75)$ CAT and pVP5 $(-50 /-168)$ CAT were kindly provided by E. Blair and E. Wagner, University of California, Irvine, CA. These plasmids contain VP5 promter -4 to $-168,-4$ to -75 , and -50 to -168 , respectively, Iinked to a reporter gene, the bacterial chloramphenicol acetyltransferase (CAT) gene and the ECORI/SalI fragment of pBR322 in which the 940 bp poison sequence was removed. The map of pVP5 (-4/-168)CAT is shown in Figure 7, the wild type VP5 promoter structure and sequence are shown in Figure 8 . pGR150B was kindly provided by G. Hayward, Johns Hopkin University. PGRI5OB is comprised of the $23.7 \mathrm{~kb} \mathrm{Bg} I \mathrm{II}-\mathrm{HM}$ fragment of HSV-2(333) which contains genes for immediatelyearly proteins IE175, IE110, IE63 cloned into the BamHI site of $\mathrm{pBR} 322$.

All of plasmid DNA were prepared by an alkaline lysis procedure of Brinboim and Doly 59 .

\section{Enzymes}

Restriction endonucleases used in this project were 
A.

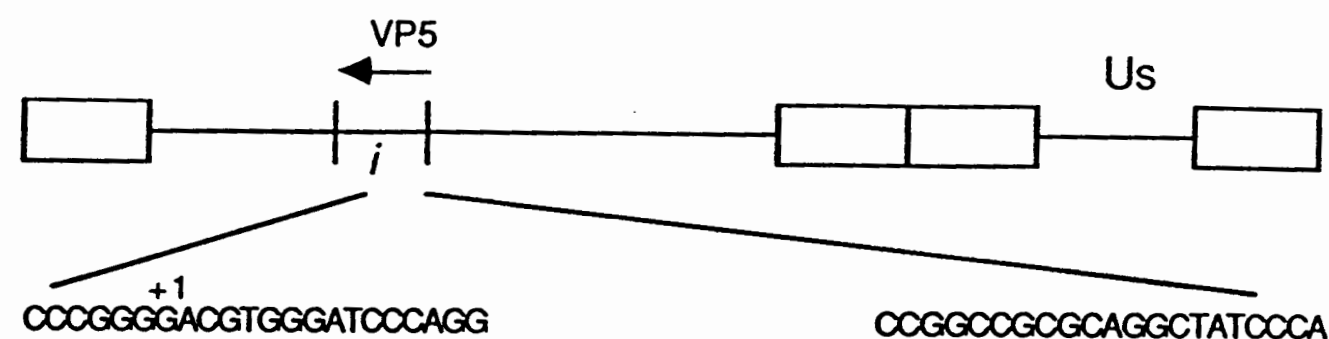

B. COCGGGGACGTGGGATCOCAGG

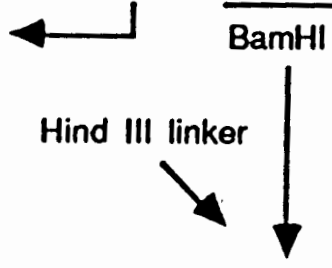

Bgl I

$-4$

VP5 Promoter

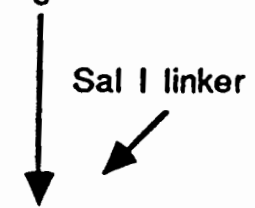

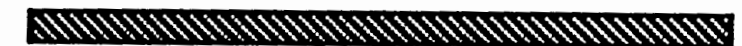

Hind III

Sal I

C.

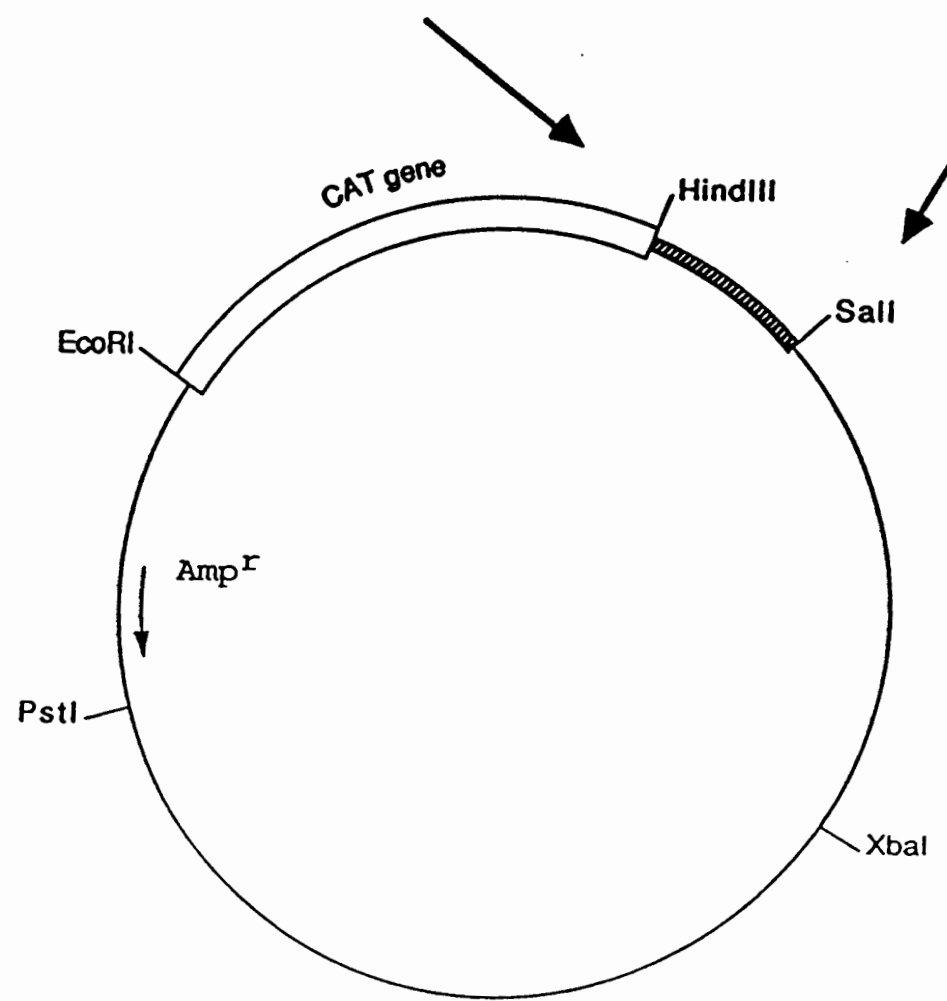

FIG. 7. A. Location of VP5 in HSV-1 genome. B. Subcloning method of VP5 (-4/-168) promoter. C. pVP5 (-4/-168) plasmid map. 
A.

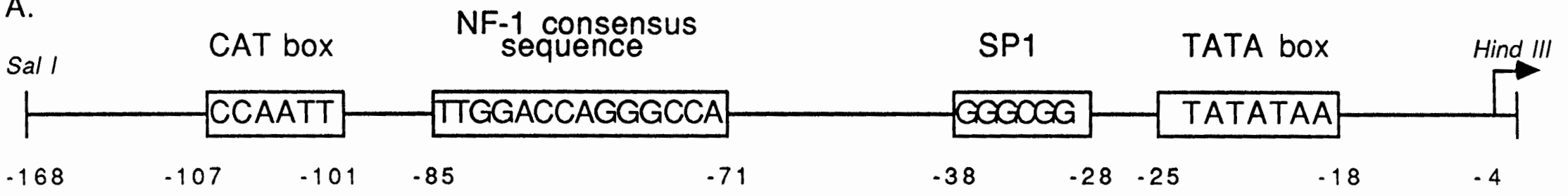

Bgl I

GGGATAGCCT GCGCGGCCGG GGCCTCGATG TGGGTGGCGG CGGCGGACAG CTTTGCCGCC CCCTATCGGA CGCGCCGGCC CCGGAGCTAC ACCCACCGCC GCCGCCTGTC GAAACGGCGG $-170$ $-150$ $-130$

\begin{tabular}{|c|c|c|c|c|}
\hline CAT & & NF-1 & & \\
\hline$=T \overline{\text { CCAATT }}$ & TCTTCCTGGC & ACGCTTTTGG ACCAGGGCCA & TCTTGAATGC & ACCCG \\
\hline $\begin{array}{l}\text { GACGGTTAA } \\
110\end{array}$ & AGAAGGACCG & $\begin{array}{l}\text { TGCGAAAACC TGGTCCCGGT } \\
-90\end{array}$ & $\begin{array}{l}\text { AGAACTTACG } \\
-70\end{array}$ & \\
\hline & Sp 1 & TATA & BamHI & \\
\hline CCTAACGGG & GGTGGGGCGG & GGGGGGTATA TAAGGCCTGG & GATCCCACGT & agragag \\
\hline AGATTGCCC & CCACCCCGCC & CCCCCCATAT ATTCCGGACC & CTAGGGTGCA & GGGGCCCA \\
\hline & & -30 & $-10+1$ & \\
\hline
\end{tabular}

FIG. 8. A. Schematic representation of VP5 promoter structure. B. The DNA sequences of VP5 promoter. 
purchased from Bethesda Research Laboratories, Inc. and New England Biolab. They were used with the appropriate 10X reaction buffer supplied by the manufacturer.

Exonuclease BAL 31, purchased from United States Biochemical Corporation, was used for exonucleolytic digestion. The klenow fragment of DNA polymerase I, T4 DNA Iigase, and RNase A, purchased from Bethesda Research Laboratories, Inc., were used for radioisotope labeling of DNA and construction of VP5 promoter mutants.

Radioactive Isotopes

$\left[\alpha-{ }^{32} \mathrm{P}\right] \mathrm{dCTP}$ was purchased from NEN Research Products,

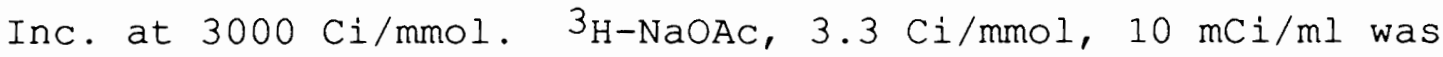
also purchased from NEN Research Products, Inc.

\section{Cells and Media}

Hela cells (CCL2) were from American Type Culture Collection. Dulbecco's Modified Eagle (DME) medium, penicillin and streptomycin were purchased from GIBCO laboratories, Inc. Bovine calf serum and fetal bovine serum were purchased from Hyclone Laboratories, Inc.

\section{Virus}

The vhs-1 mutant of HSV-1 (KOS) was kindly provided by G. S. Read. It was derived by bromodeoxyuridine mutagenesis and it is defective in the virion associated host shut-off 
function responsible for the initial suppression of host protein synthesis.

\section{Nuclear Extract}

The nuclear extracts were kindly provided by Rosemary Lawn. They were prepared according to the procedure of Dignam et al. 60 from Hela cells that were either mock infected or infected with $\mathrm{HSV}-1$ for 8 hours.

\section{PREPARATION OF DNA PROBES}

\section{Restriction digestion and DNA fragment isolation}

Plasmid DNA was mixed with $1 / 10$ total volume of $10 \mathrm{X}$ reaction buffer and 2-4 units restriction enzyme per $\mu g$ DNA. Sterile distilled water was added to keep the enzyme concentration at or below $1 / 10$ total volume and to dilute the $10 x$ reaction buffer to $1 x$ concentration. The mixtures were incubated at $37^{\circ} \mathrm{C}$, with the exception of BstNI which required $60^{\circ} \mathrm{C}$, for 2-6 hours. The incubation time depended on the activity of each enzyme (information provided by BRL). Reactions were stopped by the addition of $1 / 10$ volume of $10 x$ stop-dye (50\% (w/v) sucrose, $0.2 \mathrm{M}$ EDTA, $0.25 \%$ bromphenol blue, $0.25 \%$ xylene cyanol FF). Samples were heated at $65^{\circ} \mathrm{C}-$ $70^{\circ} \mathrm{C}$ for 3 minutes to prevent the annealing of cohesive termini and immediately chilled on ice and loaded into horizontal agarose gels. Agarose concentration in TBE buffer (0.089 M Tris-Cl, 0.089 M Boric acid, $0.02 \mathrm{M}$ EDTA pH 8) 
varied from $0.8-2.5 \%$ depending on the size of fragments. Gel was submerged in TBE buffer and run at 800-900 volt hours. Each gel also was loaded with known size markers along with DNA samples. The markers were bacteriophage lamda DNA digested with HindII and PBR322 digested with AluI. Following electrophoresis, gels were stained for 10 minutes with $0.1 \mu \mathrm{g} / \mathrm{ml}$ ethidium bromide, destained for 10 minutes with water, then visualized under a long wave UV light, and photographed with Polaroid instant pack film 667.

DNA fragments were isolated by electrophoresis onto DE81 paper, and elution from $1 \mathrm{M} \mathrm{NaCl}, 0.1 \mathrm{mM}$ EDTA, $10 \mathrm{mM}$ Tris-Cl pH 8. The eluted DNA was extracted, once with phenol and chloroform (PCIA), once with chloroform and isoamyl alcohol (CIA), precipitated with ethanol, and redissolved in $0.089 \mathrm{M}$ Tris-Cl pH 7.8, 0.089 M EDTA (TE) buffer to achieve the desired concentration 61 . DNA fragment concentration was estimated by electrophoresis on an agarose minigel along with different amounts of known DNA markers, and comparing the relative ethidium bromide staining intensities.

\section{DNA Labeling}

The 168 bp HindII/SaII fragment of VP5(168)-CAT was isolated and labeled with $[\alpha-32 \mathrm{P}]$ dCTP by Klenow fill-in reaction 62 as follows: DNA probe $(0.5 \mu \mathrm{g})$ was mixed with $1 / 10$ volume of $10 \mathrm{X}$ nick translation buffer $(0.5 \mathrm{M}$ Tris-Cl pH 7.2, $0.1 \mathrm{M} \mathrm{MgSO}_{4}, 1 \mathrm{mM}$ dithiothreitol, $500 \mu \mathrm{g} / \mathrm{ml}$ bovine serum 
albumin) and $0.1 \mathrm{nmol}$ of dATP, dTTP, dGTP, and $7.5 \mu \mathrm{Ci}[\alpha-$ 32P]dCTP, 6-8 units of klenow fragment in a total volume of $40 \mu 1$. The mixture was incubated at $37^{\circ} \mathrm{C}$ for 30 minutes and cold chased by incubation with 2 mmol of dATP, dCTP, dGTP, and dTTP for another 15 minutes. One $\mu$ mol of EDTA was added to stop the reaction. Following the klenow fill-in reaction, the sample was extracted with PCIA and CIA, unincorporated nucleotides were removed by gel filtration through an $1 \mathrm{ml}$ Sephadex G-50 spun column. The amount of $[\alpha-32 \mathrm{P}] \mathrm{dCTP}$ incorporated during the klenow fill-in reaction was measured by trichloroacetic acid (TCA) precipitation using a modification of procedure provided by Maniatis et al.

\section{MOBILITY SHIFT ASSAY}

A modification of gel mobility shift assay of Fried, $M$. and D. M. Crothers, was used to detect binding of potential regulatory proteins to the VP5 promoter region 63 .

$$
0.1-1.0 \mathrm{ng} \text { of DNA probe were mixed with } 1.3 \text { to } 6.2 \mu \mathrm{g}
$$
nuclear extract from either mock infected or $\mathrm{HSV}-1$ infected Hep-2 cell in the presence of varying amounts (4 to $13.5 \mu \mathrm{g}$ ) of poly $(d I-d C)$. Reaction buffer was added to achieve the final concentration of $6 \mathrm{mM}$ Tris-Cl, $\mathrm{pH} 7.9,40 \mathrm{mM} \mathrm{KCl}, 2 \mathrm{mM}$ EDTA, $0.2 \mathrm{mM}$ DTT, $8 \%(\mathrm{v} / \mathrm{v})$ glycerol in a total volume of 20ul. Reaction mixture were incubated at $37^{\circ} \mathrm{C}$ for 30 minutes. Two $\mu l$ of $0.25 \%$ bromphenol blue were added and the reaction mixture were analyzed by electrophoresis through $4 \frac{\circ}{0}$ 
polyacrylamide gels (acrylamide:bisacrylamide weight ratio of $30: 1)$ in $25 \mathrm{mM}$ Tris-Cl, $25 \mathrm{mM}$ Boric acid, $1 \mathrm{mM}$ EDTA at $4^{\circ} \mathrm{C}$. Gels were electrophoresed at 250 volts with buffer recirculated until bromphenol blue had run to the bottom of the gel, about 2 to 2.5 hours, and they then were transferred to Whatman 3MM paper, dried and autoradiographed with Fuji RX film with intensifying screen at $-70^{\circ} \mathrm{C}$ for 24 hours. To quantify the amount of complexes formed, the intensity of each band was measured by LKB 2202 ultrascan laser densitometer.

\section{COMPETITION BINDING ASSAY}

A number of different viral and cellular promoters were tested for their ability to compete with protein binding to the VP 5 promoter. The competitors are listed in Table 2. Reaction conditions were as described in the gel mobility shift assay procedure except that the various nonradioactive competitor DNAs were added in 10-50 fold molar excess over the labeled DNA probe.

PREPARATION OF MUTATED VP5 PROMOTER CONSTRUCTS

\section{Strategy for construction of promoter mutations}

In order to test the function of the protein binding sequence of VP5 promoter found in mobility shift assay, I constructed a series of PVP5(168)-CAT mutations in which the protein binding sequence was partially or completely deleted 
and the adjacent $\mathrm{NF}-1$ consensus sequence was split. The strategy used for these construction is shown in Figure 9.

Fragment 1 was prepared by linearizing pVP5(168)-CAT 90 ug with 180 units of SalI in a total volume of 250 ul. This fragment was subjection to digestion with exonuclease BAL 31 as follows: First, a pilot reaction was run in order to determinate the exonuclease rate. Linearied plasmid DNA 18.3 $\mu \mathrm{g}$ ) was incubated at $30^{\circ} \mathrm{C}$ with $6 \mu \mathrm{l}$ of $5 \mathrm{x}$ BAL 31 buffer ( $3 \mathrm{M}$ $\mathrm{NaCl}, 60 \mathrm{mM} \mathrm{MgCl}_{2}, 60 \mathrm{mM} \mathrm{CaCl} 2,100 \mathrm{mM}$ Tris-Cl pH $8,5 \mathrm{mM}$ EDTA) and 2.25 units of BAL31 exonuclease. Fractions of $3 \mu 1$ removed at $0,2,4,7,10,15,20,30,40$ seconds, were subjected to electrophoresis in an $0.8 \%$ agarose gel. By measuring the fragment size in each fraction, I determined that approximately 125 bp at each end of the fragment were deleted within 40 seconds.

Following the same procedure, $113 \mu \mathrm{l}$ of the remaining linearized DNA were subjected to exonuclease BAL31 deletion. According to the deletion rate, fractions of $27 \mu \mathrm{l}$ were taken after $23,26,29,32,35,38$ seconds of incubation. Three $\mu 1$ of $0.5 \mathrm{M}$ ethyleneglyclo-bis-( $\beta$-amino ethyl ether) $N, N, N, N,-$ tetracetic acid (EGTA) $\mathrm{pH} 8$ was added to each fraction to stop the reaction. All fractions were pooled into one tube and extracted with PCIA and CIA, and then precipitated with ethanol. The dry DNA pellet was resuspend in $10 \mu \mathrm{TE}$. Deleted fragments were digested with NcoI and fragments of 617-642 bp were isolated by electrophoresis in a $1 \%$ agarose 

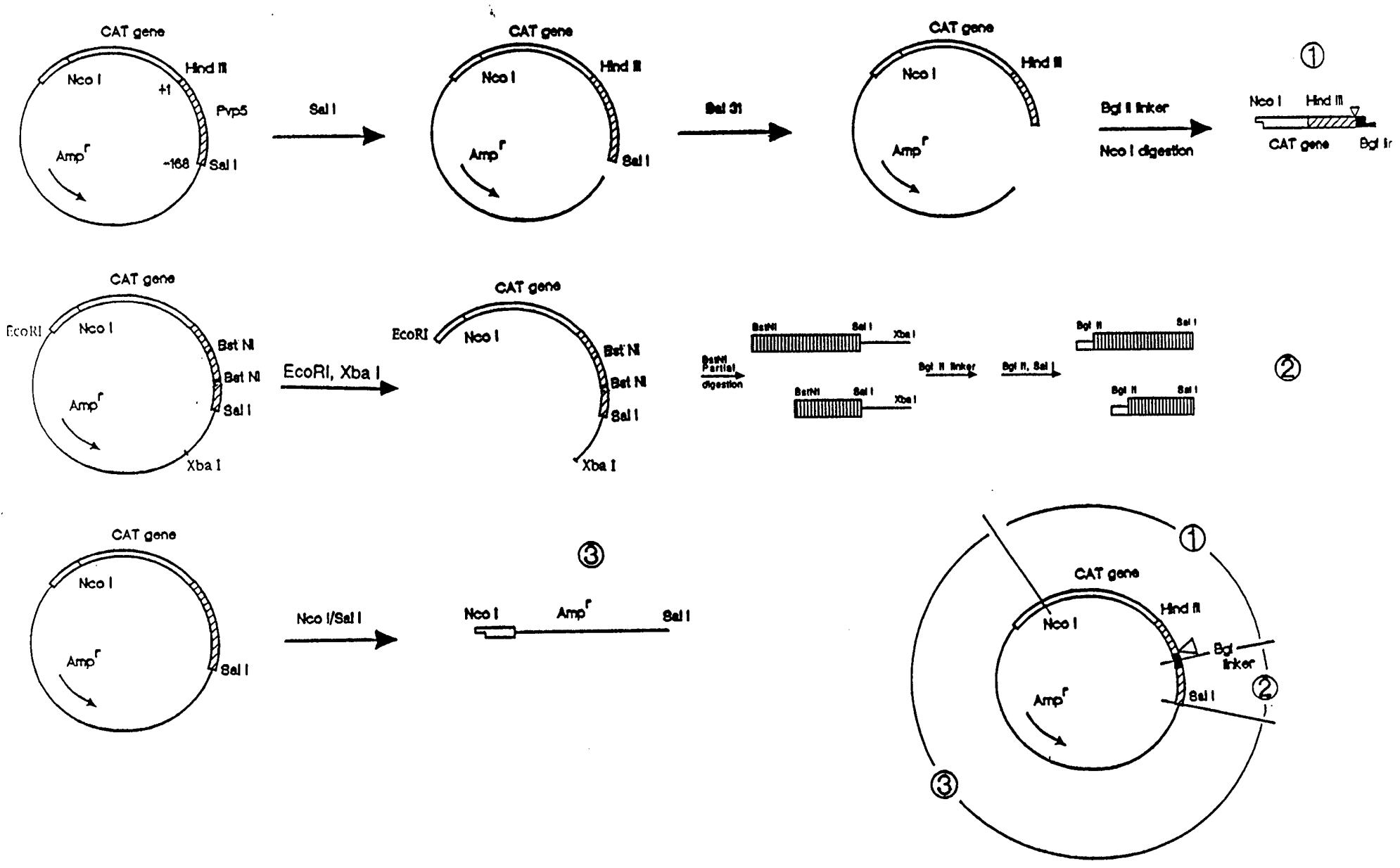

FIG. 9. Schematic representation of the strategy for constrution of VP5 promoter mutations. 
gel. The deleted/Ncol fragments were polished by filling in any non-blunt ends with the klenow fragment according to the nick translation procedure as described above.

BglII linker was purchased through New England Biolabs, Inc. T4 polynucleotide kinase and $5 \mathrm{x}$ kinase buffer, T4 DNA ligase and $5 \times$ ligase buffer were purchased from Bethesda Research Laboratories. BglII linker was phosphorylated by incubation with $1 \mu \mathrm{I} 10 \mathrm{mM}$ ATP, 20 units T4 polynucleotide kinase and $1 / 5$ volume supplied $5 \mathrm{x}$ kinase buffer at $37^{\circ} \mathrm{C}$ for 30 minutes.

Ligation protocol was provided by Maniatis et al. The deleted NcoI fragment $(6.9 \mu \mathrm{g})$ and $1.25 \mu \mathrm{g}$ BglII Iinker were mixed with 5 ul of $5 x$ Iigation buffer and 7 units of T4 DNA ligase, sterile distilled water was added to bring final volume to $25 \mu \mathrm{l}$. The mixture was incubated in $16^{\circ} \mathrm{C}$ for 16 hours and the reaction was stopped by addition of one half volume of $7.5 \mathrm{M} \mathrm{NH}_{4} \mathrm{OAC}$. Three volumes of absolute ethanol were added and the DNA was allowed to precipitate at $-20^{\circ} \mathrm{C}$ for 1 hour. The DNA was pelleted by centrifugation at 10,000xg for 30 minutes at $4^{\circ} \mathrm{C}$, vacuum dried. The DNA was digested with NCOI and BgIII to generate NCOI/BglII fragments of 650-625 bp. These fragments were purified by gel electrophresis and isolated as described above.

Fragment 2 was prepared by digesting $50 \mu \mathrm{g}$ of pVP51168) CAT plasmid with EcoI and XbaI. The 1200bp EcoRI/XbaI fragment was isolated and partially restricted with BstNI by 
controlling the incubation time. The mixture of $78 \mathrm{bp}$ and 95 bp BstNI/Xba I fragments was isolated by gel electrophoresis. After a klenow fill-in reaction to make blunt ends, phosphorylated BglII linkers were ligated to these BstNI fragments. Subsequent digestion with Bgl II and SalI generated the $84 \mathrm{bp}$ and $101 \mathrm{bp}$ BglII/SalI fragments.

Fragment 3 was prepared by digesting $10 \mu \mathrm{g}$ of pVP5 (168) CAT plasmid with NcoI and SalI. The $3020 \mathrm{bp} \mathrm{NcoI/SalI}$ fragment was isolated by agarose gel electrophoresis.

By using the same ligation procedure, equal molar amounts of fragments 1,2 and 3 were ligated together using $0.16 \mu \mathrm{g}$ fragment $1,0.02 \mu \mathrm{g}$ fragment $2,0.81 \mu \mathrm{g}$ fragment 3 , and 1 unit of $T 4$ ligase in a total reaction volume of 16.9 Hl. Ligation reaction was carried out at $+4^{\circ} \mathrm{C}$ for 16 hours. The ligation mixture was stored at $-70^{\circ} \mathrm{C}$.

\section{Selection of mutants}

Transformation. Competent HBI01 cells were purchased through Bethesda Research Laboratories Inc. The transformation procedure was also provided by BRL. Ligation mixtures were diluted in TE (1:10). Aliquots of $0.8 \mu l$ that contained $5 \mathrm{ng} l$ igated VP5 DNA were added to $20 \mu \mathrm{l}$ HB101 cells and the mixtures were incubated on ice for 30 minutes. After 40 seconds of heat shock in a $42^{\circ} \mathrm{C}$ water bath, the mixtures were chilled on ice for 2 minutes, then $80 \mu l$ soC buffer (2\% bacto-tryptone, $0.5 \%$ Yeast extract, $10 \mathrm{mM} \mathrm{NaCl}, 2.5 \mathrm{mM} \mathrm{KCl}$, 
$10 \mathrm{mM} \mathrm{MgCl} 2,10 \mathrm{mM} \mathrm{MgSO} 4,20 \mathrm{mM}$ glucose) was added and the mixture was shaked at $225 \mathrm{rpm}$ for 1 hour at $37^{\circ} \mathrm{C}$. Two additional transformation mixtures, one with the pBR322 DNA and the other without any DNA, served as controls. The transformation mixtures were streaked out on Luria Broth (LB) agar plates with $100 \mathrm{ug} / \mathrm{ml}$ ampicillin. To test the viability of HB101 competent cells, $20 \mu l$ of cells diluted into $100 \mu \mathrm{l}$ of water were spread out on a IB agar plates without ampicillin. All plates were incubated overnight at $37^{\circ} \mathrm{C}$.

Restriction analysis. From the transformation, forty three ampicillin resistant colonied were picked and innoculated separately in $4 \mathrm{ml}$ of Luria broth containing 50 $\mu \mathrm{g} / \mathrm{ml}$ ampicillin. Plasmid DNAs were prepared from each clone by a quick plasmid preparation. Each sample was analyzed by restriction endonuclease digestion. Pst was used to linearize mutated DNA, ECoRI and SalI were used for three cuts, and EcoRI, SalI and BglII provided four cuts in the recombinant plasmids.

From the restriction analysis, eight mutant clones which appeared to contain the desired range of deletions in the VP5 promoter sequences were selected.

DNA sequencing. The plasmid DNAs from eight pVP5(-4/168) CAT mutants were obtained by large scale plasmid DNA preparation. 
i. Preparation of labeled DNA fragments

The plasmid DNA from pVP5 (-4/-168)CAT and its mutants were linearized by SalI digestion and labeled with $[\alpha-$ 32 P]dCTP by klenow fill-in reaction as described above. After a second digestion with PvuII, 32 P-labeled SalI/PvuII fragments, ranging from 290 to $317 \mathrm{bp}$, were isolated from agarose gels.

ii. DNA sequencing

A modification of Maxam-Gilbert protocol64, was used to determine the DNA sequences of mutated VP5 promoters. For each end-labeled DNA fragment, a set of four reactions were set up: a) methylation of the DNA with dimethyl sulfate for cleavage at $G$ sites. b) partial depurination in sodium formate provide in approximately equal cleavage at $G$ sites and A sites. C) treatment with hydrazine for cleavage at C and $T$ sites. d) treatment with hydrazine and sodium chloride to cleave only at $C$ sites.

Five $\mu l$ of each sequencing reaction was loaded onto an 8\% polyacrylamide gel (acrylamide:bisacrylamide ratio $28: 1$, $7.7 \mathrm{M}$ Urea). Electrophoresis was carried out at 1500-2000 volts until the loading dye moved approximately two-thirds of the way down the gel. Gels were fixed in solution of 95\% acetic acid and $5 \%(\mathrm{v} / \mathrm{v})$ methanol for 10 minutes, and transferred to Whatman $3 M M$ paper, vacuum dried, exposed to Euji RX film for 48 hours at $-70^{\circ} \mathrm{C}$ with KODAK intensifying screen. 
TRANSFECTION AND CAT ASSAYS

\section{Transfection}

Four mutated VP5 promoter constructs were selected for analysis. They were \#2 in which the sequence from -83 to -93 was replaced by BglII linker, \#6 in which the BglII linker was inserted into the BstNI site in the NE-1 consensus sequence, \#10 in which NF-1 site and half of the binding sequence were deleted, and mutant \#13 in which NF-1 site and the binding sequence were completely deleted. (see Fig. 10). These mutant plasmids, along with the wild type pVP5(-4/168) CAT, were tested in transient-expression assays for CAT gene expression.

Hela cells (CCL2) from American Type Culture Collection were propagated in Dulbecco's Modified Eagle (DME) medium containing $10 \%$ heat inactivated calf serum and $100 \mathrm{units} / \mathrm{ml}$ of penicillin, $100 \mu \mathrm{g} / \mathrm{ml}$ of streptomycin at $37^{\circ} \mathrm{C}$, under a $5 \%$ $\mathrm{CO}_{2}$ atmosphere. They were routinely passaged every 5 days at a $1: 15$ split ratio.

Hela cells were seeded in $35-\mathrm{mm}$ six-well cluster dishes at $3 \times 10^{5}$ cells per well approximately 20 hours before transfection. After 17 hours, the medium was removed and cells were re-fed with $2.5 \mathrm{ml}$ DME containing $10 \%$ heat inactivated fetal cattle serum and penicillin(100 unit/ml) and streptomycin $(100 \mu \mathrm{l} / \mathrm{ml}) \quad(\mathrm{DME}+10 \% \mathrm{IFCS}+\mathrm{P} / \mathrm{S})$. Three hours later, each $35 \mathrm{~mm}$ well of subconfluent monolayer was 


\section{MUTATED VP5 PROMOTERS}

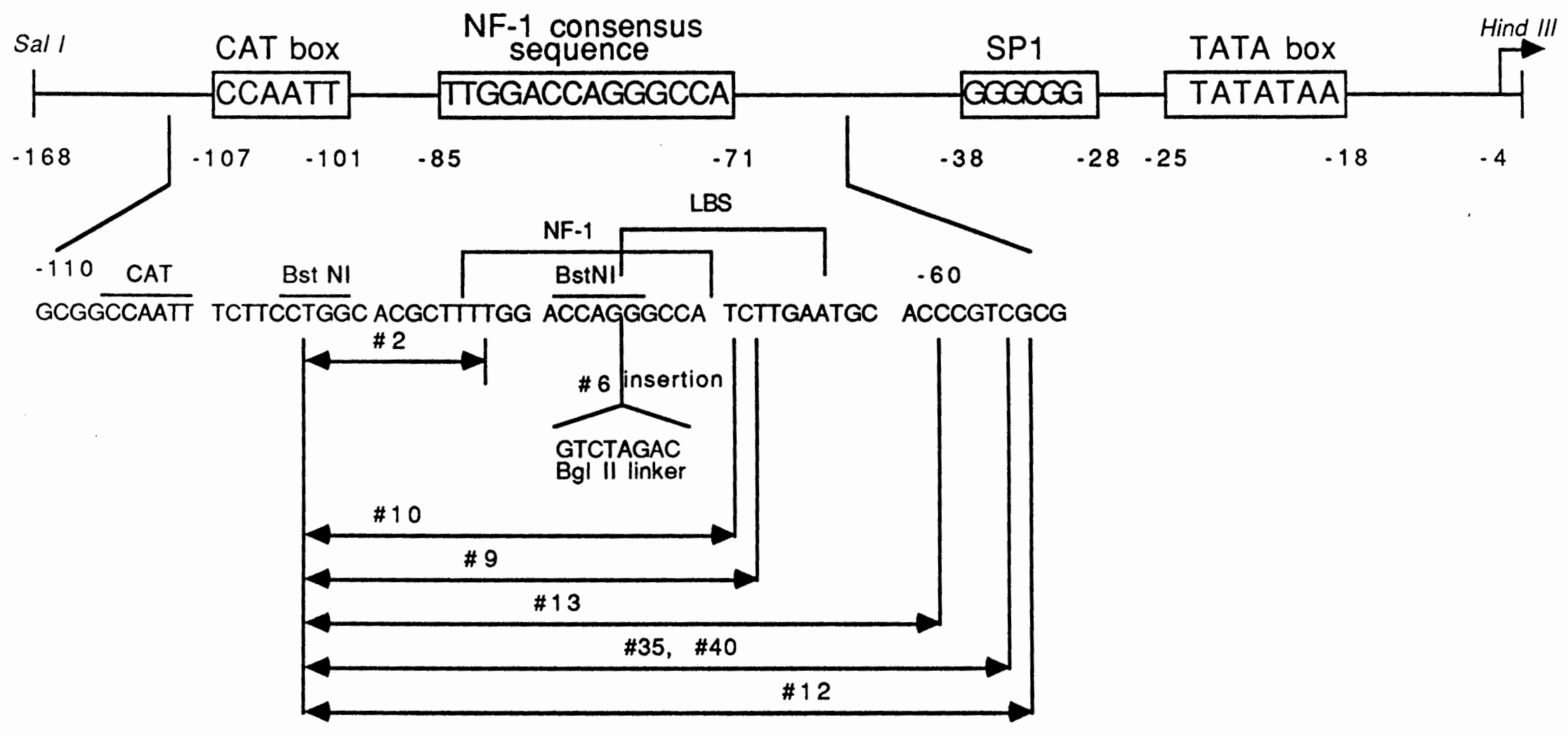

FIG. 10. Mapping of deletion and insertion constructs in the VP5 promoter. Insertion \#6 contains an inserted BglII linker. Sequences between the arrows of all the deletion constructs were replaced by BglII linker. LBS and NF-1 consensus sequence were indicated. 
transfected with $0.5 \mathrm{mI}$ DNA-calcium phosphate coprecipitates which contained $5 \mu \mathrm{g}$ target plasmid and $11 \mu \mathrm{g}$ carrier puc18 DNA or $8 \mu \mathrm{g}$ target plasmid and $8 \mu \mathrm{g}$ cotransfected effector plasmid, pGR150B65. Four hours after the DNA was added, the cells were shocked by adding to their medium $1 \mathrm{ml} 15 \%$ glycerol in minimal essential medium for 1 minute, then the cells were washed with PBS-A $10.14 \mathrm{M} \mathrm{NaCl}, 2.7 \mathrm{mM} \mathrm{KCl}, 4.3 \mathrm{mM}$ $\left.\mathrm{Na}_{2} \mathrm{HPO}_{4}, 1.5 \mathrm{mM} \mathrm{KH} \mathrm{PO}_{4}\right)$, and incubated further in DME+10\% IFCS+P/S. Transfected cells were either superinfected with the vhs-1 mutant of HSV-1 at multiplicity of infection of 3 for 20 hours after transfection, and harvested 26 hours later for CAT assay, or directly harvested for CAT assay 44 hours after DNA transfection.

\section{CAT assay}

The procedure of Nordeen et al. was used as a rapid, sensitive and inexpensive assay for chloramphenicol acetyltransferase activity 66 .

Cell extract preparation. At 26 hours postinfection for virus superinfected cultures, the cell monolayers were washed twice with cell wash buffer $(40 \mathrm{mM}$ Tris-HCl pH 7.4, $150 \mathrm{mM} \mathrm{NaCl}, 1 \mathrm{mM}$ EDTA), scraped from the cluster dishes and sedimented by low speed centrifugation. Cell pellets were resuspended in $100 \mu l 250 \mathrm{mM}$ Tris-HCl, $\mathrm{pH}$ 7.8. The cells were frozen at $-20^{\circ} \mathrm{C}$, thawed at room temperature for four times and then debris were removed by centrifugation at 
$10,000 \mathrm{rpm}$ at $4^{\circ} \mathrm{C}$ for 10 minutes. Cell extracts were stored at $-70^{\circ} \mathrm{C}$.

CAT enzyme assay. Chloramphenicol, ATP, bacterial

chloramphenical acetyl transferase, S-acetyl coenzyme A synthetase, and coenzyme A were purchased from Sigma Chemical Company.

Reaction mixtures containing $31.5 \mu l$ of $4 x$ Assay buffer (400 mM Tris-HCl pH 7.8, $24 \mathrm{mM} \mathrm{MgCl} 2,300 \mathrm{mM} \mathrm{KCl}$ ) were thoroughly mixed with 0.008 units of s-acetyl coenzyme A synthetase, $5 \mu \mathrm{l}$ of $0.78 \mu \mathrm{Ci} / \mu \mathrm{I} 3 \mathrm{H}$-NaOAC, $10 \mu \mathrm{l}$ of $5 \mathrm{mM} \mathrm{COA}, 4$ $\mu l$ of $100 \mathrm{mM} \mathrm{ATP}$ and $0.5 \mu \mathrm{l}$ of Chloramphenicol in a total volume of $95 \mu l$. S-acetyl coenzyme A synthetase were added last to initiate the reaction. The reaction mixtures were incubated at $37^{\circ} \mathrm{C}$ for $30 \mathrm{~min}$ to generate labeled acetyl CoA. Thirty ul of cell extract was added and reaction mixtures were further incubated for 2 hours. The labeled chloramphenicol was extracted by vigorous shaking with $1 \mathrm{ml}$ benzene. The benzene and aqueous phases were then separated by centrifugation in a microcentrifuge at $4^{\circ} \mathrm{C}$ for 15 minutes. An $800 \mu l$ aliquot of the benzene phase was placed in a plastic scintillation vial and dried by evaporation in a fume hood overnight. The residue was counted in $3 \mathrm{ml}$ of scintillation fluid and radioactivity determined in a liquid scintillation spectroscopy, Beckman LS 9000. The CAT assay results were also confirmed by thin-layer chromatography and autoradio-graphy. After the $800 \mu \mathrm{l}$ aliquots of the benzene 
phase were dried in a fume hood overnight, they were redisolved in $50 \mu \mathrm{l}$ of benzene and spotted on a KODAK silica gel thin-layer chromatography (TLC) plate. Chromatography was carried out with chloroform-methanol (95:5) as the solvent. The TLC plate was dried in a fume hood overnight and then exposed to Fuji RX X-ray film to visualize the acetylated chloramphani-col. After autoradiography, the labeled region of the TLC plate were excised and the radioactivity determined by Beckman LS 9000 liquid scintillation counter. 
CHAPTER IV

\section{DISCUSSION}

The Complexes Formed by VP5 LBS and YY1

Promoter activities are regulated by the interaction of numerous site-specific DNA-binding proteins with their recognition sequences. A fundamental property of many sitespecific DNA-binding activators is their ability to stimulate transcription synergistically with other factors which recognize the same sequence or adjacent sequences. In the mobility shift assay in this study, two DNA-protein complexes were formed with both mock-infected and HSV-1 infected nuclear extracts. Although the VP5 promoter is a typical eukaryotic promoter and requires three immediate-early proteins (ICPO, ICP4, and ICP27) for transactivation, there was no viral specific complex formed. The mobility shift result indicated that a cellular factor (or factors) is involved in the formation of the complexes and that the HSV-1 immediatly-early proteins do not binds directly or only weakly bind to the VP5 promoter.

Other HSV-1 promoters from different kinetic classes, and promoters from other viruses and some cellular genes, were tested in competition assay. Most of them were not able 


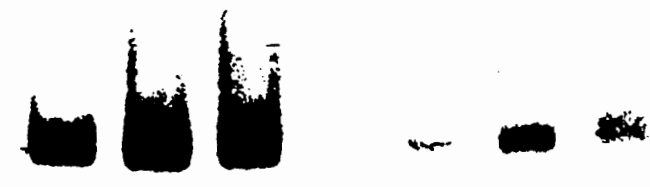

B
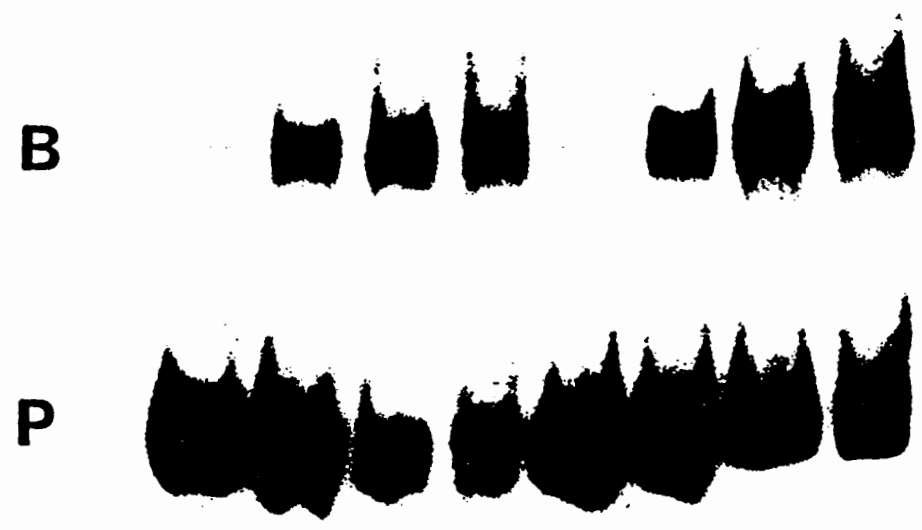

\section{$\begin{array}{llllllllll}1.3 & 2.5 & 3.7 & 6.2 & 1.3 & 2.5 & 3.7 & 6.2 & \mu \mathrm{g}\end{array}$ \\ Mock-infected HSV-1 infected nuclear extract nuclear extract}

FIG. 11. Gel mobility shift analysis of the VP5 promoter. Various amount of nuclear extracts from either uninfected or HSV-1 infected Hela cells were reacted with $0.1 \mathrm{ng}$ of VP5 promoter fragment (-4 to -168 bp relative to the cap site, end labeled with $[\alpha-32 \mathrm{P}] \mathrm{dCTP})$. Amount of nuclear extracts used, in micrograms of protein per reaction, and positions of the two major complexes ( $A$ and $B$ ) formed and free probe (P) are indicated. 
were either mockinfected or infected with HSV-1 for 8 hours (Fig. 11). The reaction products were analyzed by electrophoresis on polyacrylamide gels. Two complexes were formed with both mockinfected or HSV-1 infected nuclear extracts. The larger complex, of lower mobility, was designated complex $A$ and the smaller one was designated complex B. Although gene expression studies of immediatelyearly gene mutants of HSV-1 have shown that $\beta \gamma$ gene expression required viral IE proteins67, no viral specific complex was observed in this experiment. IE proteins may indirectly bind to VP5 promoter or binds weakly to VP5 promoter. This mobility shift assay result also indicates that some cellular factors are involved in forming the two complexes.

To determine the promoter specificity of these complexes, a series of competition binding assays was carried out by using a number of different viral promoters. A HindII/SalI fragment (-4 to $-168 \mathrm{bp})$ of VP 5 promoter labeled with $\left[\alpha-{ }^{32} \mathrm{P}\right] \mathrm{dCTP}$ was used as probe, and the competing, nonlabeled DNA fragments used were promoters from HSV-1 genes of different kinetic classes. Since the protein binding sites LBS previously identified in the VP 5 promoter overlapped with a nuclear factor-1 (NF-1) consensus sequence, a DNA fragment containing the $\mathrm{NF}-1$ sequence of adenovirus-2 was also tested in the competition binding assay (see Table 1). The results of these experiments (some presented in Figure 12) indicate 


\section{TABLE 1. VARIOUS SEQUENCES TESTED IN THE MOBILITY SHIFT ASSAY}

\section{Competitor Fragment and Source}

1. 430 bp PstI/KpnI fragment of pCA23

190 bp AvaII fragment of pCA23

2. $370 \mathrm{bp}$ EcoRI/SstII fragment of pDII

3. $200 \mathrm{bp}$ HindIII/KpnI fragment of p2.7-CAT

4. 214 bp PstI/PvuII fragment of pHSV-106

5. 620 bp SmaI/Pst I fragment of HSV-106

\section{Content}

$\alpha-$ TIF promoter

$\mathrm{NF}-1$ site of adenovirus-2

UL14/15 (2.7 $\beta \gamma$ gene) promoter

$5.2 \mathrm{~kb} \beta \gamma$ gene promoter

HSV-1 gH promoter 
that none of the promoter fragments I tested compete with the VP5 promoter DNA in the formation of complexes $A$ and $B$. Likewise, the failure of the adenovirus-2 NF-1 DNA fragment to compete suggests that the NF-1 consensus sequence present on the VP5 promoter is not responsible for complex $A$ and $B$ formation. However, Millette's results68 showed that the HSV-1 promoters $\mathrm{gD}$ and $\mathrm{gB}$, and an internal fragment of the UL37 gene competed with VP5 promoter to form the complexes. These results, taken together with others from Millette's lab, indicate that the observed complexes are very likely specific for the VP5 promoter and certain $\beta \gamma$ genes of HSV-1 (see Table 2).

To determine the boundaries of the VP5 DNA sequences involved in the formation of complexes $A$ and $B$, two subfragments of the VP5 promoter region were used, VP51$4 /-75)$, containing the sequence from -4 to -75 and $\operatorname{VP} 5(-50 /-$ 168), containing the sequence from -50 to -168 relative to the mRNA cap site (see figure 13). They were excised from plasmid pVP5 (-4/-75) CAT and pVP5 (-50/-168) CAT respectively. In the first experiment, a $[\alpha-32 \mathrm{P}] \mathrm{dCTP}$ labeled HindIII/SalI fragment of the VP5 promoter, VP5 (-4/-168), was used as probe, and 50-fold molar excess amount of VP5 promoter subfragments were served as competitors. Both the VP5(-4/75) and VP5 (-50/-168) competed. In the second experiment, a [ $\alpha-$ 32 P] dCTP labeled VP5 (-50/-168) fragment was used as probe while 50-fold molar excess amount of non-labeled VP5 $(-4 /-75)$ 


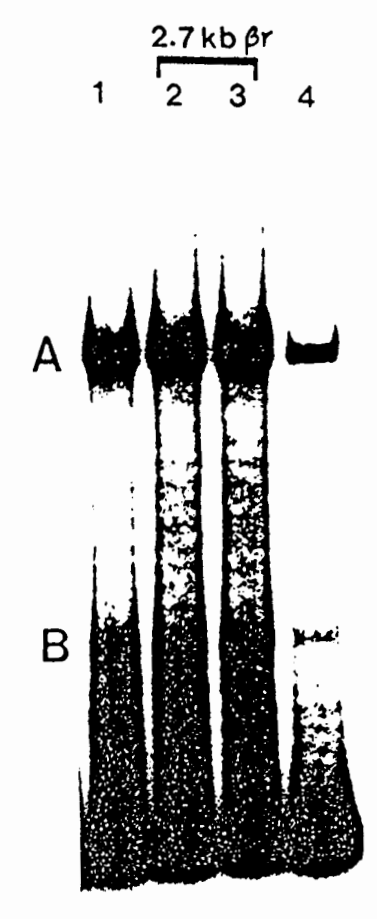

A. $2.7 \mathrm{~kb} \beta \gamma$ (UL14/15)

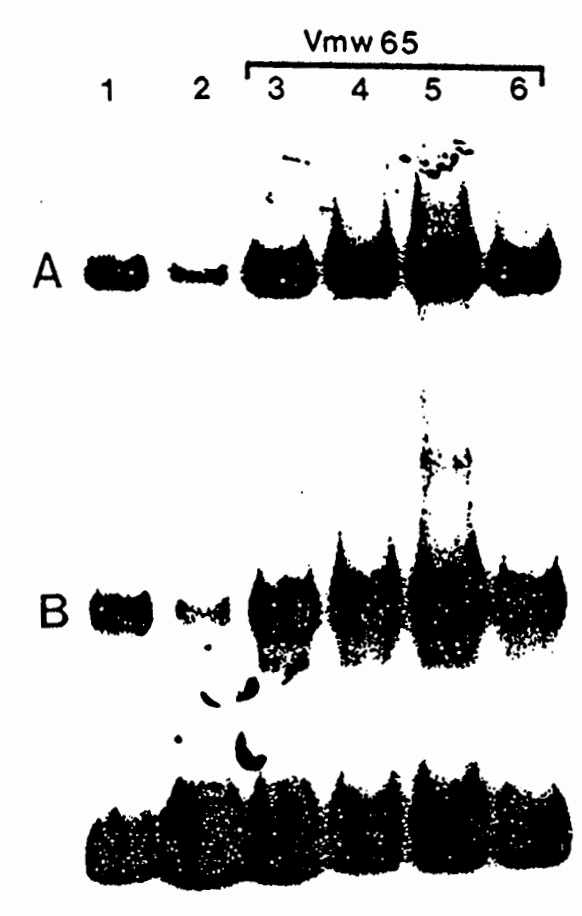

B. Vmw 65 promoter

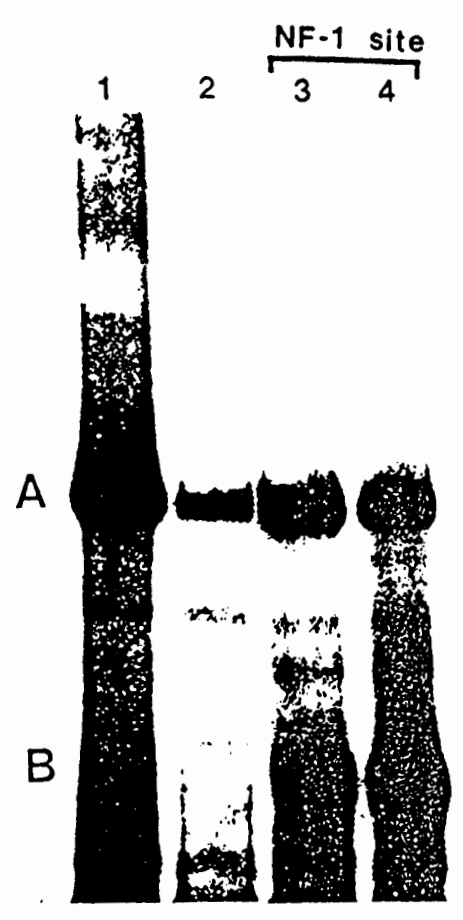

C. Ad-2 origin (Incl. NF-1 site)

FIG. 12. Competition of VP5 promoter complex formation by unlabeled DNA fragments. $32 \mathrm{P}-1$ abeled VP5(-4/168) promoter and $3.7 \mu \mathrm{g}$ of protein of infected Hela nuclear extract presented in all reactions. All Lane 1 were probe only. Lane 4 in $A$, lane 2 in $B$ and $C$, are positive control, which 40-fold molar excess of unlabeled VP5(-4/-168) were used as competitor. A. Lane 2 and 3, 20- and 40-fold unlabeled UL14/UL15 fragment as competitor, respectively. B. lane 3 and 4,20 - and 40-fold 190 bp $\alpha$-TIF promoter as competitor; lane 5 and 6,20 - and 40 -fold 430 bp $\alpha$-TIF promoter as competitor. C. lane 3 and $4,20-$ and 40-fold unlabeled 370 bp fragment which contains adenovirus-2 NF-1 site as competitor. 
Table 2. Competition of VP5 Promoter Complex Formation by Unlabeled Viral and Cellular DNA Fragments

Source of

fragments
DNA fragments showing:

No competition
HSV-1 DNA

$g \mathrm{H}, \mathrm{gC}(\gamma)$

$\mathrm{UL} 14 / 15$

UL2 4

UL $37-137$

UL 46

$\operatorname{VP} 16(\beta \gamma)$

TK

UL40 ( $\beta$ )

$\operatorname{ICP} 47(\alpha)$

Adenovirus

type-2 DNA

Major late promoter

$\mathrm{NF}-1$ site

Cellular DNA

$\boldsymbol{\varepsilon}$-globin promoter

Competition 
$\operatorname{VP5}(-4 /-168)$

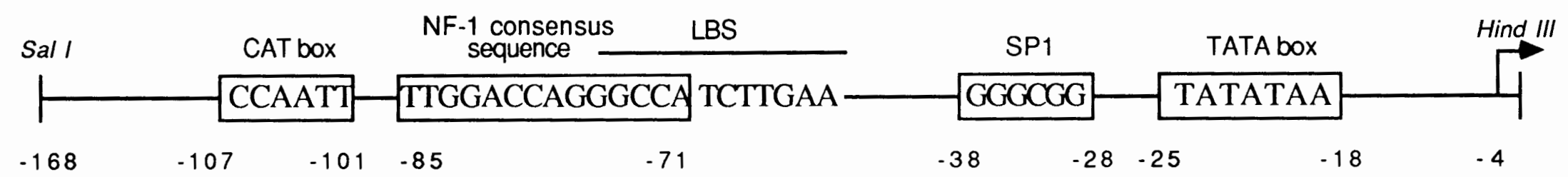

$\operatorname{VP5}(-50 /-168)$

LBS

$\vdash_{-168}$ CCAATT TTGGACCAGGGCCA TCTTGAA-

VP $5(-4 /-75)$

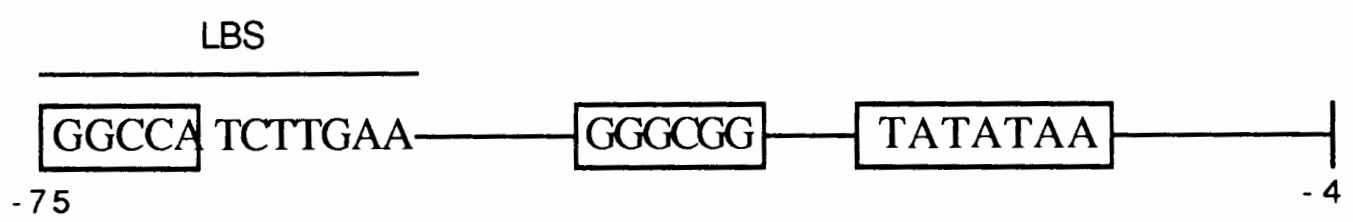

FIG. 13. Diagram of VP5 $(-4 /-168)$ promoter and its subfragments, VP5 $(-4 /-75)$ and VP5 $(-51 /-168)$. 
served as competitor; the VP5(-4/-75) fragment showed good competition (see figure 14). These results indicate that complexes $A$ and $B$ involve DNA sequence located in the overlap region of the two VP5 promoter subfragments, the sequence from -50 to -75 relative to the cap site.

DNase I footprinting and orthophenanthroline-Cu+ analysis 68 confirmed the location of complexes. The results show that Complex $A$ involves the sequence from -64 to -75 , and complex $B$ involves sequence from -63 to -76 relative to the VP5 cap site. Both complexes encompass a common core promoter sequence GGCCATCTTGAA, designated the Leaky-late Binding Site (LBS), located from -64 to -75 relative to the cap site (see figure 15).

\section{ANALYSIS OF MUTANTS}

\section{Complex formation by the mutated VP 5 promoters}

To assess the role of the VP5 promoter Leaky-Late Binding Site (LBS) in the transcriptional regulation of the VP5 gene, a series of mutated VP5 promoter constructs were generated from pVP5 (-4/-168) CAT by deletion and insertion around the protein binding site LBS. The isolation procedure involved, in brief, opening pVP5(-4/-168) CAT at a BstNI site, exonucleolytic digestion with nuclease BAL 31, connecting an $8 \mathrm{bp}$ BglII linker, and ligating the appropriate fragment back together (See Materials and Methods). The mutant constructs isolated and used in these studies are shown in Figure 16. 
A.

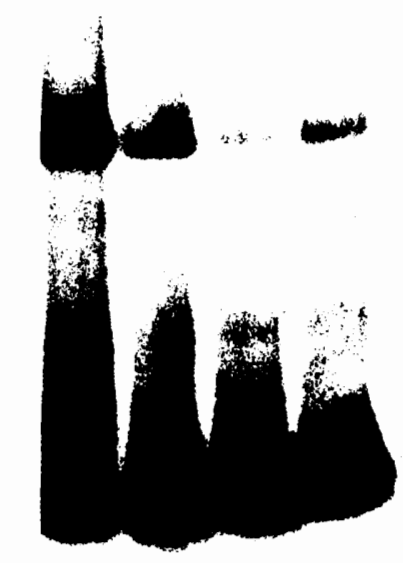

VP5(-4/-168) Probe

VP5 $(-4 /-168)$ fragment

VP5 $(-51 /-168)$ fragment

VP5(-4/-75) fragment

Nuclear Extract, Poly(dl-dC)

\section{$\# 1 \quad \# 2 \quad \# 3 \quad \# 4$}
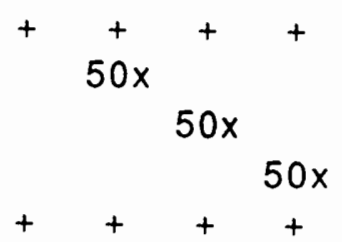

B.

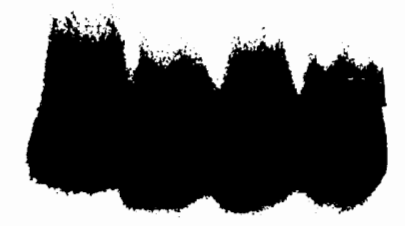

VP5(-51/-168) Probe VP5 $(-51 /-168)$ fragment VP5(-4/-75) fragment Nuclear Extract, Poly(dl-dC)

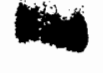

\#1 \#2 \#3 \#4

$+$

$50 x$

$20 \times 50 x$

FIG. 14. Competition binding assay between the VP5 $(-4 /-168)$ promoter and its subfragments. A. VP5 $(-4 /-168)$ as probe. Lane 1, probe only, without competitor; lane $2-4$, unlabeled 50-fold molar excess of VP5 $(-4 /-168)$, VP5 $(-51 /-168)$, and VP5 $(-4 /-75)$, respectively. B. VP5 $(-51 /-168)$ as probe. Lane 1, probe only; lane 2, unlabeled 50-fold molar excess of VP5 $(-51 /-168) ;$ lane 3 and 4 , unlabeled 20 and 50 -fold molar excess VP5 $(-4 /-75)$. $3.7 \mu g$ of protein of infected Hela nuclear extract presented in all lanes. Poly $(d I-d C)$ were used for nonspecific binding. 


\section{Location of Complex $A$ and $B$}

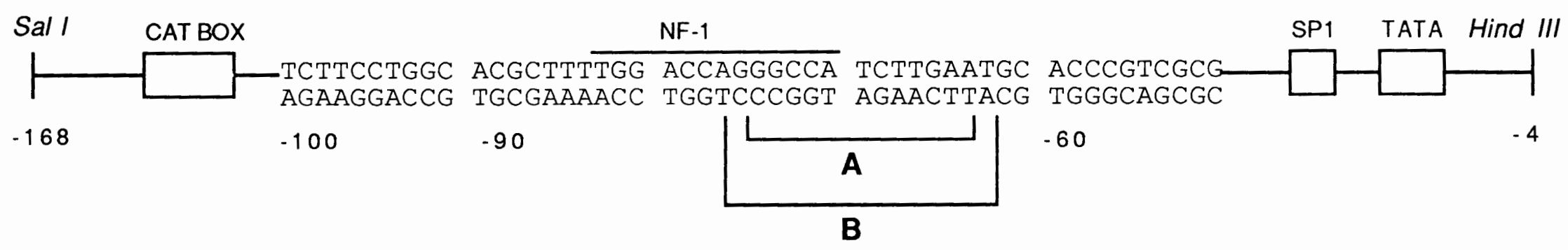

FIG. 15. Diagram showing protected regions of the VP5 promoter in DNase I footprint assay. The VP5 TATA box and potential Sp1, CAT box, and NF-1 sites are indicated. 


\section{MUTATED VP5 PROMOTERS}
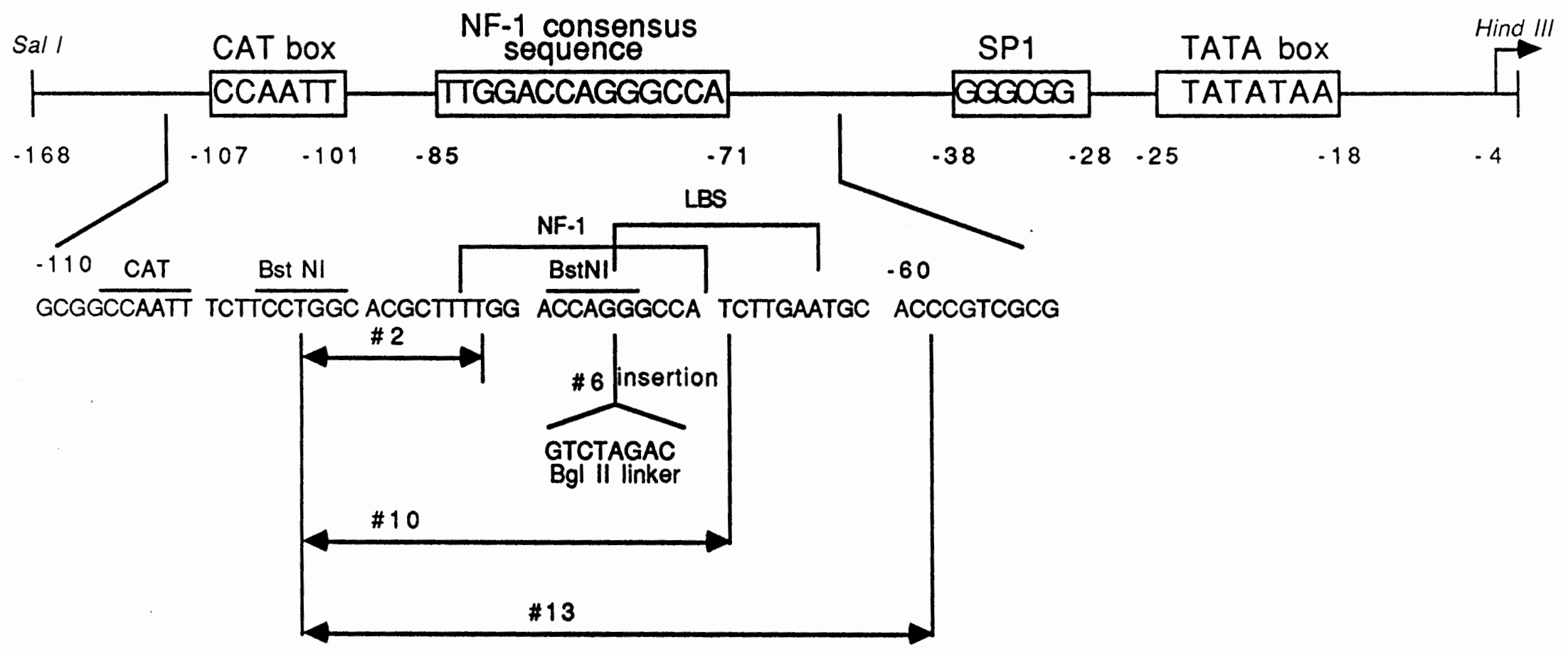

FIG. 16. Diagram of mutated VP5 promoters tested in this project. Insertion \#6 contains an BglII linker. Sequences between the arrows of all the deletion constructs were replaced by an BglII linker. IBS and NF-1 consensus sequence were indicated. 
They were construct \#2 in which sequence from -83 to -93 was deleted, \#6 which contained an 8 bp Bgl II linker insertion between -80 to -81 thereby splitting the NF-1 consensus sequence, \#10 in which the sequence from -70 to -93 containing NF-1 consensus site and half of LBS was deleted, and \#13 in which the NF-1 consensus site and the LBS were completely deleted.

Mutated VP5 promoter from constructs \#2, \#6, \#10 and \#13 were tested as competitors in competition binding assay to determine the relation between promoter sequences and the ability to form complexes $A$ and $B$. The molar ratio of radiolabeled probe to the competitor was $1: 20$ and $1: 40$, (See Figure 17). The results of these experiments showed that the mutated VP5 promoter of mutant constructs \#2 (data not shown) and \#6 were capable of competing as well as the wild-type VP5 promoter, whereas the mutated VP5 promoter of \#10 only partially competed and that of \#13 completely failed to compete. These data indicate that the deletion of sequence from -83 to -93 in construct \#2 and the 8 bp insertion between -80 and -81 in \#6 does not affect the formation of complexes $A$ and $B$. Deletion of sequence from -70 to -93 in construct \#10 partially affects the formation of both complexes and the deletion of sequence from -59 to -93 in construct \#13 completely eliminates complex formation. Therefore, sequence from -80 to -59 is most likely involved in the formation of both complexes directly. 


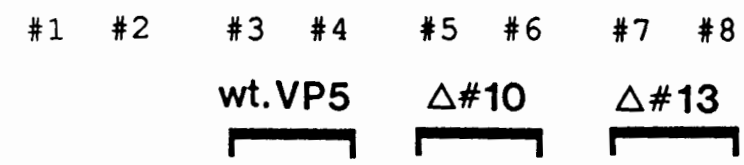

A

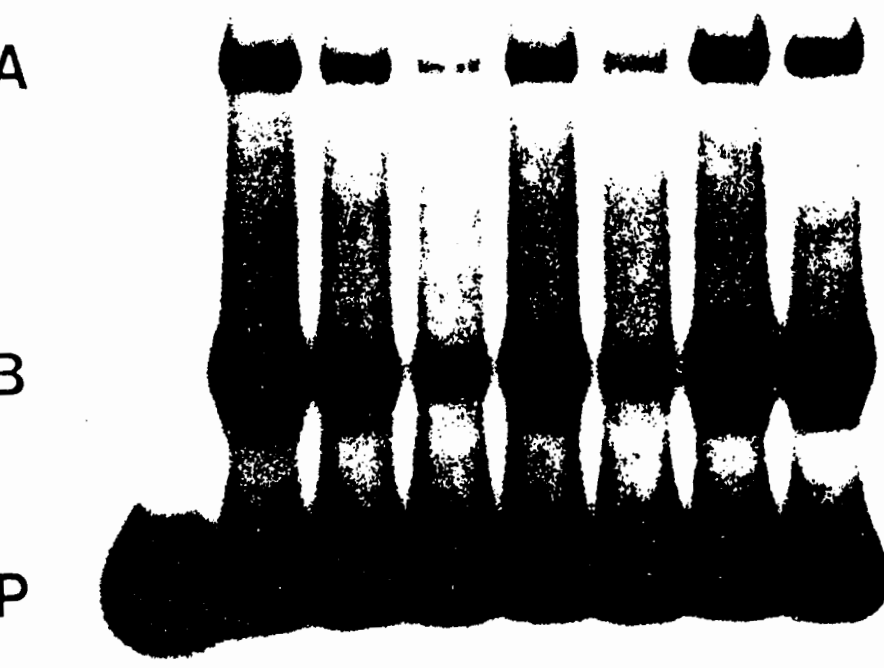

\#9 \#10 \#11 \#12 \#13

wt.VP5

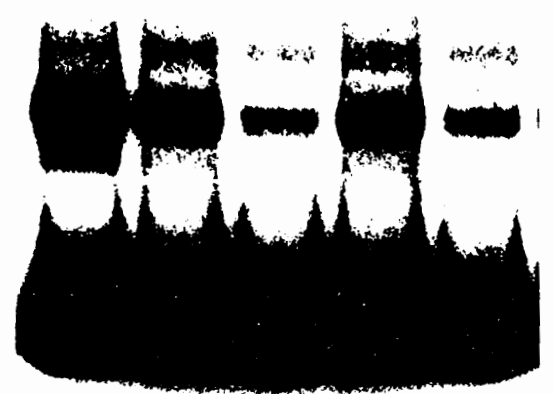

FIG. 17. Competition binding of labeled VP5 promoter versus unlabeled mutated VP5 promoter fragments. Gel mobility shift assay was carried out with $3.7 \mu \mathrm{g}$ of protein of infected Hela nuclear extract. A, B, and $P$, complexes A and B and free probe respectively; lane 1, free probe; lane 2 and 9, 32P labeled VP5 $(-4 /-168)$ without competitor. For the remain lanes, 20- and 40-fold molar excesses of the indicated wild-type or mutated VP5 promoter fragments were used as competitors. 
The prometer activity in transient expression assay

To analyze the role of the complexes in the regulation of VP5 gene expression, the wild-type VP5 promoter (sequence -4 to -168 ) and mutated VP5 promoters were tested in transient expression assays with or without viral transactivation to investigate the effects of the mutation on promoter ability to drive expression of the bacterial chloramphenicol acetyl transferase gene at both basal level and induced level.

Hela cells were transfected with either wild-type VP5(4/-168)-CAT or mutated VP5 promoter constructs. The cells were either harvested 45 hours after transfection, or they were superinfected with the vhs-1 mutant of HSV-1 KOS strain 24-26 hour after transfection, and then harvested 26 hours later. These results are presented in Figure 18. Without viral transactivation, both wild type VP5 promoter and mutated VP5 promoters were basically inactive. The levels of CAT expression driven by these promoters were essentially same as that in the untransfected cell. With virus superinfection, however, CAT activity of $\operatorname{VP} 5(-4 /-168) \mathrm{CAT}$ increased 424 fold whereas construct \#6 having an 8 bp insertion disrupted the NF-1 consensus sequence increased 351 fold. As with construct \#6, the deletion in construct \#2 had only a small effect in CAT activity (data not shown). Deletion of half of LBS (\#10) reduced the transactivaion level to 92 fold whereas deletion of all LBS (\#13) produced 


\section{Induction of VP5 Promoter Constructs by HSV-1 Superinfection}

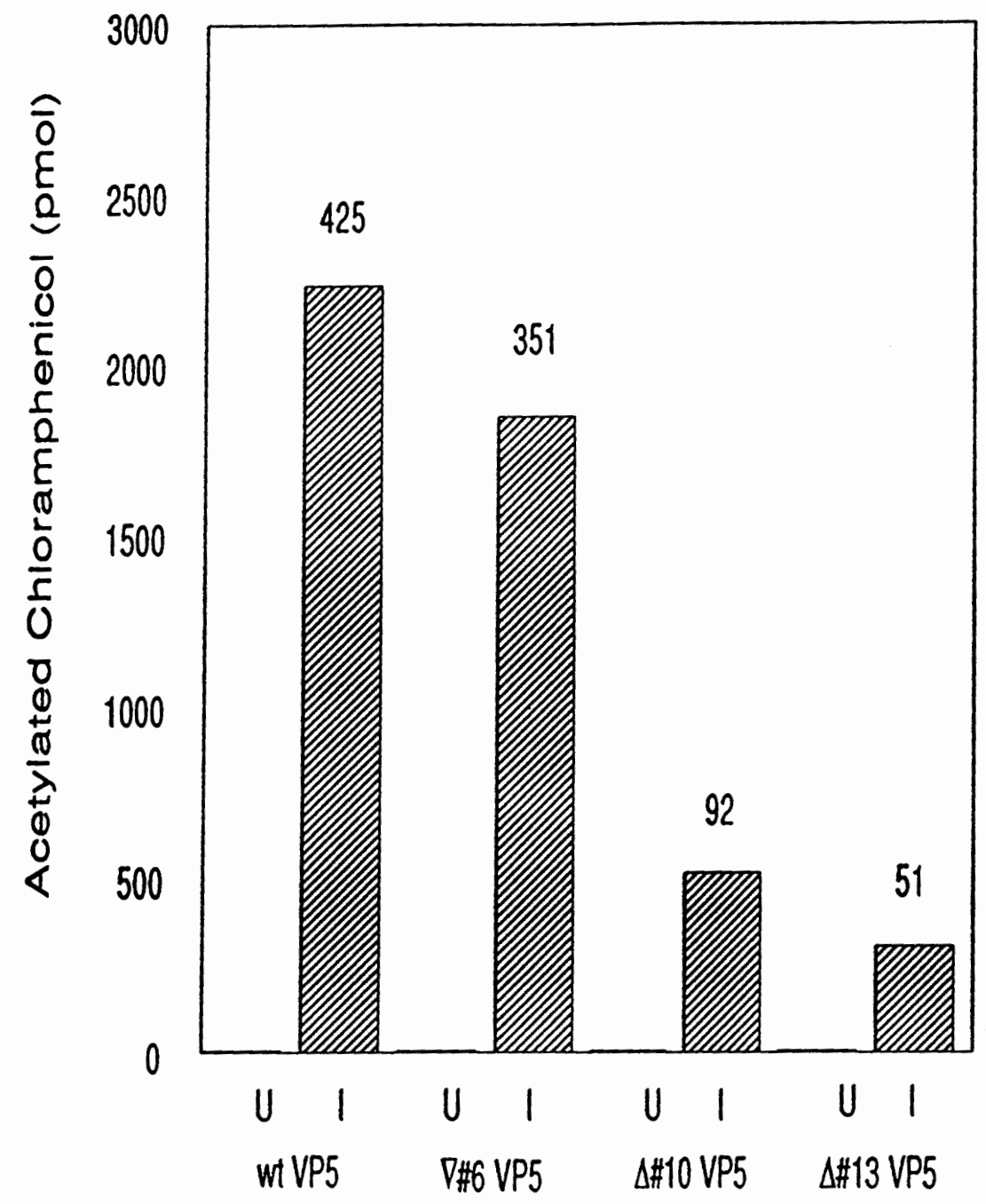

FIG. 18. Induction of transfected VP5 promoter-CAT constructs by HSV-1 superinfection. Amount of acetylated chloramphenicol produced is expressed as picomoles of the monoacetylated form produced in 2 hours at $37^{\circ} \mathrm{C}$ with 25 $\mu l$ of cell extract. U represent uninduced levels, and I represents induced levels. Number on the bar graph indicate fold-induction over uninduced levels. Average uninduced CAT levels was 5.6 pmol of acetylated chloramphenicol. The data represent averages of a minimum of three separate transfection assays. 
only 51 fold induction by superinfecting virus. Therefore, deletion of LBS resulted in about 8 -fold reduction in the level of viral transactivation of the VP5 promoters. These results suggest that the LBS may activate the VP5 promoter by binding to the cellular factor and this is required for the maximum VP5 expression under viral superinfection.

Early studies HSV-1 mutations in other laboratories have reported that three HSV-1 IE genes (encoded ICPO, ICP4, and ICP27) were required for VP5 promoter activation. The requirement of all three viral proteins was tested in the transient expression assay. Plasmid pGR150B contains the immediate-early gene ICPO, ICP 4 and ICP27. Plasmid pGR90 contains ICPO, ICP4 and ICP 47 gene, and PGRI62 contains ICP 27 gene only. Plasmid pVP5 (-4/-168)CAT along with one of the above plasmids were used to cotransfect the cells. The CAT activity induced by pGR150 was 69.8 times over the uninduced level, whereas the CAT activities induced by either pGR90 or PGR162B remain about the same as the uninduced level (see Fig. 19). This comfirmed the necessity for all three immediately-early viral proteins in VP5 transactivation.

The involvement of LBS in the viral proteins transactivation process was tested in further transient expression assay. Cotransfected plasmid, pGR 150B provided the three viral immediately proteins (ICPO, ICP4, and ICP27) required for activating late gene promoters (see figure 19). The results showed that transactivation by IE genes increased CAT 


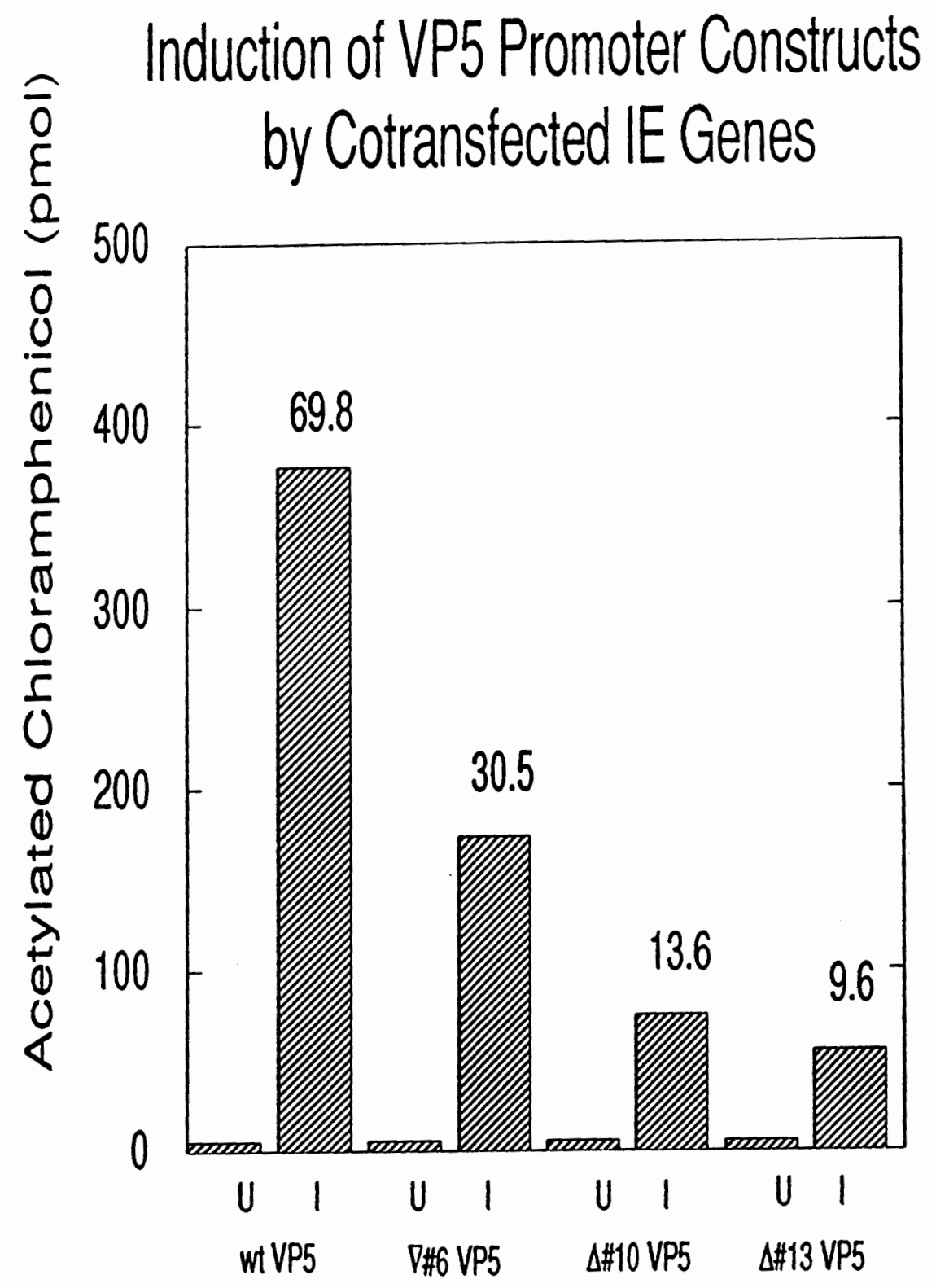

FIG. 19. Induction of transfected VP5 promoter-CAT constructs by cotransfected plasmid, pGR150B, contains HSV genes for ICPO, ICP4, and ICP27. Amount of acetylated chloramphenicol produced is expressed as picomoles of the monoacetylated form produced in 2 hours at $37^{\circ} \mathrm{C}$ with 25 $\mu l$ of cell extract. U represent uninduced levels, and I represents induced levels. Number on the bar graph indicate fold-induction over uninduced levels. Average uninduced CAT levels was $5.6 \mathrm{pmol}$ of acetylated chloramphenicol. The data represent averages of a minimum of three separate transfection assays. 
activity of pVP5 (-4/-168) CAT 69.8 fold over the uninduced level, whereas \#6 increased it 30.5 fold, \#10 increased it 13.6 fold, and \#13 increased it only 9.6 fold. Thus deletion of the LBS resulted in a 7.1 fold reduction in gene expression relative to that of the wild type VP5 promoter. These results indicate that even though the LBS has not been shown to directly associate with viral proteins, it is required for optimal level of transactivation by superinfecting $\mathrm{HSV}-1$ or cotransfected HSV-1 IE proteins. In addition, the LBS sequence appears to have no effect on the uninduced level of promoter activity.

A Computer search of GeneBank has shown that homologies to LBS exist in many viral genes and cellular genes. The homologies and their locations are listed in Table 3. 
Table 3. Promoter Sequences Homologous to the VP5 LBS Sequence

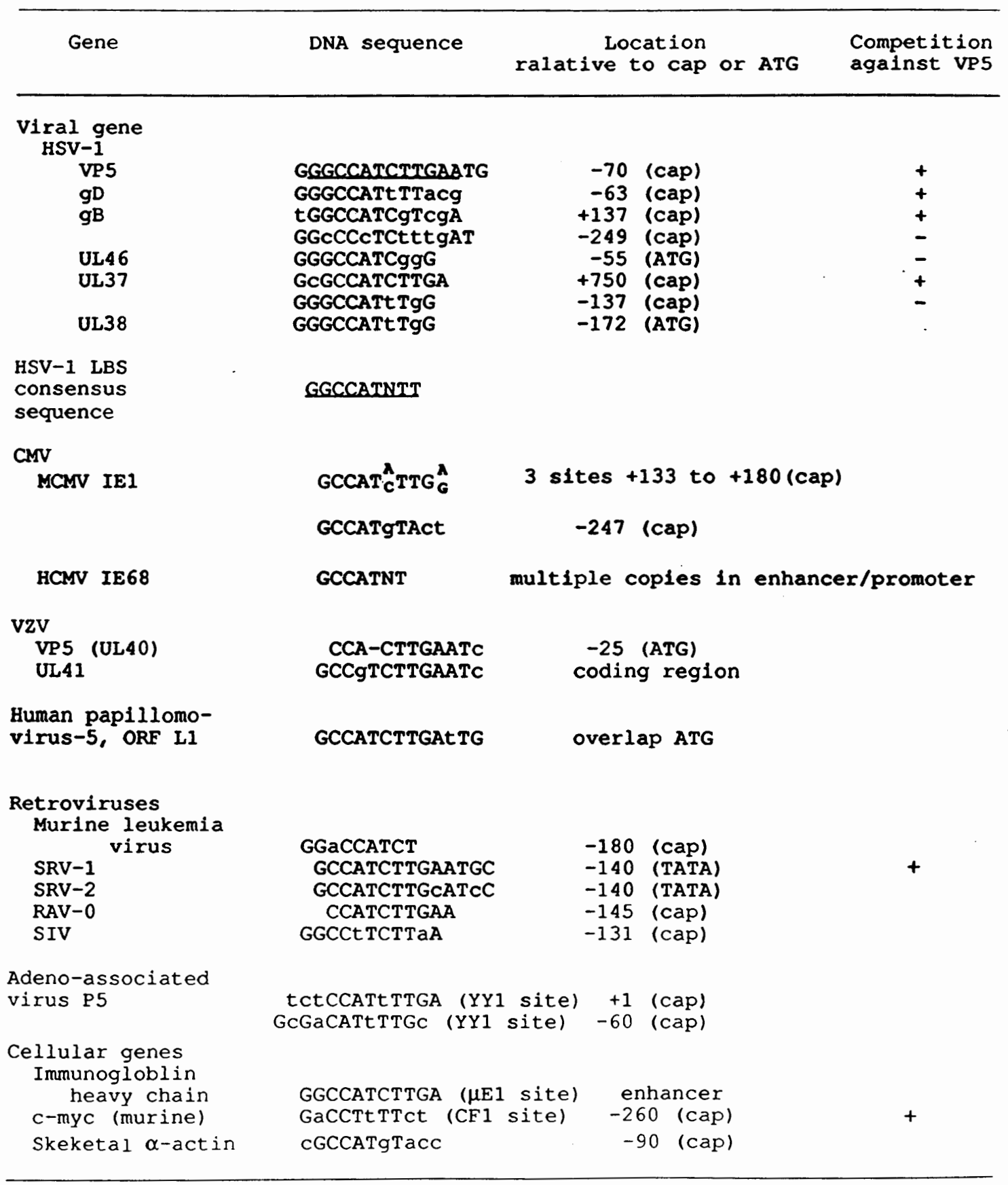


CHAPTER IV

DISCUSSION

The Complexes Formed by VP5 LBS and YY1

Promoter activities are regulated by the interaction of numerous site-specific DNA-binding proteins with their recognition sequences. A fundamental property of many sitespecific DNA-binding activators is their ability to stimulate transcription synergistically with other factors which recognize the same sequence or adjacent sequences. In the mobility shift assay in this study, two DNA-protein complexes were formed with both mock-infected and HSV-1 infected nuclear extracts. Although the VP5 promoter is a typical eukaryotic promoter and requires three immediate-early proteins (ICPO, ICP4, and ICP27) for transactivation, there was no viral specific complex formed. The mobility shift result indicated that a cellular factor (or factors) is involved in the formation of the complexes and that the HSV-1 immediatly-early proteins do not binds directly or only weakly bind to the VP5 promoter.

Other HSV-1 promoters from different kinetic classes, and promoters from other viruses and some cellular genes, were tested in competition assay. Most of them were not able 
to form the complexes, except the gD promoter, a fragment from the nontranslated leader region of $g B$, and a UL37 gene fragment (see Table 2). These genes, like VP5, all belong to the HSV-1 $\beta \gamma$ kinetic class. Further studies from the Millette labortory showed that the promoters of HSV-1 gB, gD and human c-myc gene competed with the VP 5 promoter by binding to the same protein 68 .

There is a consensus nuclear factor-1 (NF-1) binding site upstream of the LBS that partially overlaps with the LBS. NF-1 was originally isolated from Hela nuclei as a host factor required for efficient initiation of adenovirus DNA synthesis in vitro69. Subsequently, NF-1 was shown to be identical to the cellular factor CTF (CCAAT-binding transcription factor) and play a role in transcription 70 . A number of $\mathrm{NF}-1$ binding sites have been identified upstream of various cellular and viral genes. In this study, partial deletion of LBS and NF-1 consensus binding site in mutant \#10 reduced complex formation, and complete deletion of LBS and NF-1 consensus binding site in mutant \#13 resulted in elimination of the complexes. The involvement of $\mathrm{NF}-1$ consensus sequence to the protein-DNA complexes was tested in competition binding assay. A forty-fold molar excess of a DNA fragment which contains an adenovirus-2 NF-1 site and origin was unable to compete with the VP5 promoter sequence to form the complexes. Also, An 8 bp insertion in the middle of the NF-1 consensus site of mutant \#6 did not change the 
ability of VP5 promoter to form the complex. Therefore, it is unlikely that the $\mathrm{NF}-1$ is involved in the formation of complex $A$ and $B$. .

By treating the DNA/protein complexes with V8 endoprotease, Millette and Mill's partial proteolysis study revealed the similar subcomplex patterns among the complexes formed by VP5 promoter, gD promoter or human c-myc promoter with nuclear extract, and complexes formed by VP5 promoter with YY1 protein 71 . They also showed that a monoclonal antibody to YYl inhibited formation of complexes $A$ and $B$. Their result indicated that the protein which forms the complexes $A$ and $B$ is cellular factor YYI.

Based on following observation in their laboratory, Millette and Mills suggested that the smaller complex (B) results from proteolytic cleavage of the YYI protein that forms complex A, and either two forms of YY1 exist in the cell or they were formed during nuclear extract preparation: 1) DNase I and orthophenanthroline-Cu${ }^{+}$footprint analysis 68 showed that complex A and B formed over a core sequence GGCCATCTTGAA (LBS) located from -64 to -75 relative to Cap site. 2) A radiolabeled oligonucleotide containing only the LBS site formed both complexes. 3) V8 endoprotease digestion of the nuclear extract complexes resulted in the same pattern of subcomplexes as that observed with the YY1 complex. 4) A monoclonal antibody to YY1 inhibited formation of both complexes. 
The Effect of LBS In VP5 Transactivation of Viral Factors

Previous studies of Smiley and Everett using DNA transfection showed that the VP5 promoter was relatively inactive in uninfected cells, but it was effectively transactivated by a superinfecting virus, HSV-1, or by three immediately early gene products: ICPO, ICP4 and ICP27.

In Costa and Wagner's early study, the activities of different length VP5 promoters were tested in transient expression assays. The VP5 promoter sequence from +1 to -75 had detectable activity in uninfected Hela cells, whereas the VP5 promoter sequence from +1 to $-125,+1$ to -168 , or +1 to -650 were completely inactive in transfected HeLa cells in the absence of HSV induction. However, with HSV-1 infection, even though the the VP5 promoter sequences +1 to -75 was sufficient to allow expression with HSV superinfection, it induced at least 10 fold less CAT expression than that of VP5 promoter from +1 to $-125,+1$ to -168 , or +1 to -650 . In addition, no more than 125 bp of VP5 promoter was found to be sufficient for the maximum expression. This suggested that some feature of the VP5 promoter sequence between -75 to -125 blocked the uninfected cell's ability to recognize the VP5 promoter in the CAT expression assay and that this region of the VP5 promoter may also be involved in achieving full activity from this promoter after HSV superinfection 55 . 
In my research project, wild-type VP5 promoter $(-4 /-168)$ and mutated VP5 promoters, ranged from -59 to -93 relative to cap site, were tested in transient expression assays to elucidate the effects of the mutation on promoter activity. Wild type VP5 promoter and all mutated VP5 promoters have undetectable activity in uninfected cell. This result further suggest that the sequence from -94 to -125 may have a blocking or repressing effect. CAT gene expression driven by wild-type VP5 promoter increased 425 fold with HSV-1 superinfection over that of uninfected control. Insertion of $8 \mathrm{bp}$ in the middle of NF-1 consensus sequence, as well as deletion from $-82 \mathrm{bp}$ to $-93 \mathrm{bp}$ in \#2, slightly reduced CAT gene expression. Deletion of complete protein binding site and NF-1 consensus sequence resulted in only 51 fold induction. This amounted to a 8.3-fold reduction in viral transactivation, and a level of CAT gene expression that was only 13\% that of wild type. Similar results were obtained from co-transfection of VP5 promoters with a plasmid containing genes for three HSV immediately-early proteins, ICPO, ICP4, and ICP27. These results suggest that LBS plays an important role in optimal level VP5 gene expression. The increase in expression mediated by the $\mathrm{NF}^{-1}$ binding site may be is additive with, and independent of, the enhancement by the VP5 LBS. The significance of each should be tested in transient assay by deletion of either NF-1 consensus site or the protein binding site, LBS. Complete deletion of LBS in 
VP5 promoter did not reduce promoter activity to the control level. This suggested that another region of VP5 promoter also must be involved in the transactivation process, and that interaction of multiple factors may be required for maximal transactivation of the VP5 promoter.

A Computer analysis of GeneBank have shown that homologs of LBS exist in many viral genes and cellular genes. The homologs and their locations are listed in Table 3 . In HSV-1, several late genes showed sequences highly homologous to LBS. Millette's data showed that three other HSV-1 $\beta \gamma$ promoters $(g B, g D$, and UL37) competed for the factor binding to LBS; two potential $\beta \gamma$ promoters (UL14/15, UL24) did not compete. In Everett's early study of gD promoter, deletion analysis showed that the promoter region which contains the LBS homolog was very critical for viral transaction of the gene. The VP5 promoter of Varicella-Zoster virus, and the late promoter of human papillomovirus-5 also contain LBS homologs.

The most interesting finding is the existance of LBS homologs in the long terminal repeat of many retroviruses. These include both simian retrovirus 1 which causes simian acquired immune deficiency syndrome (SAIDS), and simian retrovirus 2 which induces retroperitoneal fibromatos is in addition to SAIDS. These LTRS contain 8 to $14 \mathrm{bp}$ of LBS homologies located about 130-150 bp upstream from the mRNA start site. Millette's laboratory found that a fragment of 
the SRV-1 LTR that contains a 14 bp perfect match to the VP5 LBS formed two complexes of similar mobility to the VP5 complexes, and an oligonucleotide containing the VP5 LBS effectively competed with the SRV-1 fragment for cellular protein binding 68. LBS homologies also occur in the long terminal repeat of human AIDS virus HIV-1 and a human retroprovirus, and deletion studies have shown this region of the long terminal repeat may play a role in transcriptional regulation. Herpes simplex virus 1 and 272 , cytomegalovirus73, and human herpesvirus $6^{74}$ are among of a number of viruses have shown be able to activate gene expression driven by the HIV long terminal repeat and enhancer. Even though no specific binding between ICPO and HIV-1 LTR found, the transfection study of Pitha et al. have showed that ICPO can activate the HIV-1 long terminal repeat promoter region and the effect of ICPO can greatly enhanced in the presence of cellular factor $\mathrm{NF}-\mathrm{KB}^{75}$. The spl sites located on the HIV-1 LTR also served as target sites of transactivation by HSV176. The next interesting question is, does the VP5 LBS homolog in the HIV long terminal repeat play a role in the transactivation of HIV.

The recognition site for common factor $I$ (CF1) in the cellular immunoglobin heavy chain enhancer, skeletal $\alpha$-actin promoter, and c-myc promoter also showed homologies with LBS. CF1, a protein which binds the upsteam of the murine c-myc PI promoter, was identified by mobility shift assay and 
footprint assay 77 . The CFl binding activity was found in all cultured cells and normal tissues tested78. Riggs et al. have recently published results showing that CF1 is identical to $Y Y 1^{79}$.

YY1, also known as NF-E1, UCRBP, and $\delta$, is a ubiquitously expressed zinc finger protein. The binding sites for YYl are widely distributed in many cellular and viral promoters 80 . In many instances, YY1 act as a transcriptional repressor 81,82 , e.g. in the adeno-associated virus P5 promoter, immunoglobulin $\mathrm{k} 3^{\prime}$ enhancer, and c-fos promoter, etc., whereas in other cases it appears to be an activator of transcription 83, for example, in the c-myc promoter, and IgH intronic enhancer. In Natesan and Gilman's paper, they presented the evidence that YYI regulates the activity of the c-fos promoter primarily through an effect on DNA structure. YY1 binds to the promoter and induced a phased DNA bend at three sites. YY1 repressed the c-fos promoter activity, but activated the same promoter when the YY1 binding site was reversed. They concluded that the major function of YYI in c-fos promoter is to bend DNA to regulate contact between other proteins 84 . In the case of HSV-1, it is possible that the bending of VP5 promoter caused by YY1 enhances the interaction between general transcription factor and Spl or CAT box binding protein. Finally, there are several reports about the physical interaction between YY1 and Sp185. This suggest that Sp1 may exert its effect on VP5 promoter 
activity in an indirect way by affecting how YYl interacts with VP5.

DNA bending and looping play an important role in the regulation of transcription, replication and recombination in bacteria86, 87. Many mammalian transcription factors have been reported bend $\mathrm{DNA}^{88,89}$. Natesan and Gilman suggested that some transcription factors, e.g. YY1, may have no intrinsic activation or repression function of their own, but may induce structural changes such as bends in the DNA helix to facilitate other protein-DNA interaction. It will be interested to investigate the YYI function when the LBS orientation reversed.

Some of the VP5 LBS homologs are found in introns or the coding sequences of other viral genomes and cellular genes. It is hard to determine the significance at this point, but an increasing number of intragenic elements which affect gene transcription have been reported90, and some researchers have reported regulatory elements that are located within protein-encoding sequences 91 .

In summary, the research findings in this project are presented as following: 1) Two DNA-protein complexes were formed with the HSV-1 VP5 promoter. The VP5 regulatory sequence, LBS, is responsible for the formation of these complexes, and the cellular protein involved, later proved by Millette and Mills, is YY1. 2) Mutation analysis showed that the LBS is required for maximum levels of VP5 transactivation 
either by superinfecting HSV-1 or by cotransfected IE HSV-1 genes, ICPO, ICP4, and ICP27. 3) Homologs of the LBS occur throughout the HSV-1 genome and other viral genome, as well as some cellular genes. Millette and Mills showed HSV-1 gD, gB, and UL37 genes also form the complexes with YY1. This suggested that the regulation in VP5 is very likely relevant to several other HSV-1 $\beta \gamma$ genes. Some of the homologs studied in other laboratories, for example, the homologs in adeno-associated virus P5 promoter and in immunoglobulin heavy chain enhancer, have shown to play an important role in the transcription regulation. 
References:

1. Ginsbery, H. S. 1988. Herpesviruses. Virology.

2. Roizman, B. Virology

3. Yao, F., and R. J. Courtney. 1989. A major transcriptional regulatory protein (ICP4) of herpes simplex virus type 1 is associated with purified virons. J. Virol. 63:3338-3344

4. Yao, F., and R. J. Courtney. 1992. Association of ICPO but not ICP 27 with purified virions of herpes simplex virus type. J. Virol. 66:2709-2716

5. Heine JW, Honess RW, Cassai E, Roizman B. Proteins specified by herpes simplex virus. XII. The virion polypeptides of type 1 strains. J. Virol 1974; 14:640651 .

6. Cai, H. H., B. Gu, and S. Person. 1988. Role of glycoprotein B of herpes simplex virus type 1 in viral entry and cell fusion. J. Virol. 61:714-721.

7. Weber, P. C., M. D. Challberg, N. J. Nelson, $M$. Levine, and J. C. Glorioso. 1988. Inversion events in the HSV-1 genome are directly mediated by the viral replication machinery and lack sequence specificity. Cell. 54:369-381

8. Jenkins, F. J., B. Roizman. 1986. Herpes simplex virus recombinants with noninverting genomes frozen in different isomeric arrangements are capable of independent replication. J. Virol. 59:494-499

9. WuDunn, D., and P. G. Spear. 1989. Initial interaction of herpes simplex virus with cells is binding to heparan sulfate. J. Virol. 63:52-58.

10. Herold, B. C., D. WuDUNN, N. Soltys, and P. G. Spear. 1991. Glycoprotein C of herpes simplex virus type 1 plays a principal role in the absorption of virus to cells and in infectivity. J. Virol. 65:10901098.

11. Ligas, M. W., and D. C. Johnson. 1988. A herpes simplex virus mutant in which glycoprotein $D$ sequences are replaced by $\beta$-galactosidase sequences binds to but is unable to penetrate into cells. J. Virol. 62:14861494 .

12. Cai, W. H., B. Gu, and S. Person. 1988. Role of glycoprotein B of herpes simplex virus type 1 in viral entry and cell fusion. J. Virol. 62:2596-2604.

13. Fuller, A. O., R. E. Santos, and P. G. Spear. 1989. Neutralizing antibodies specific for glycoprotein $\mathrm{H}$ of herpes simplex virus permit viral attachment to cells but prevent penetration. J. Virol. 63:3435-3443.

14. Spaete R. R, Frenkel N. 1985. The herpes simplex virus amplicon: analysis of cis-acting replication functions. Proc. Natl. Acd. Sci. USA 82:694-698 
15. Olive, P. D., N. J. Nelson, and M. D. Challberg. 1988. Herpes simplex virus DNA replication: the UL9 gene encodes an origin binding protein. Proc. Natl. Acad. Sci. USA 85:5414-5418

16. Crute, J. J., T. Tsurumi, I. Zhu, S. K. Weller, P. D. Olive, M. D. Challberg, E. S. Mocarski, and I. R. Lehman. 1989. Herpes simplex virus 1 helicase-primase: a complex of three herpes-encoded gene products. Proc. Natl. Acad. Sci. USA 86:2186-2189.

17. Powell, K. I., E. Littler, and D. J. M. Purifoy. 1981. Nonstructural proteins of herpes simplex virus. II. Major virus specific DNA-binding protein. J. Virol. $39: 894-902$

18. Chartrand, P., C. S. Crumpacker, P. A. Schaffer, and $\mathbf{N}$. M. Wilkie. 1980. Physical and genetic analysis of the herpes simplex virus DNA polymerase locus.

19. Gottlieb, J., A. I. Marcy, D. M. Cohen, and $M$. D. Challberg. 1990. The herpes simplex virus type 1 UL42 gene product: a subunit of DNA polymerase that functions to increase processivity. J. Virol. 64:59765987

20. McGeoch, D. J., M. A. Dalrymple, A. J. Davisib, A. Dolan, M. C. Frame. D. McNab, L. J. Perry, J. E. Scott, and P. Taylor. 1988. The complete DNA sequence of the long unique region in the genome of herpes simplex virus type 1. J. Gen. Virol. 69:15311574

21. McGeoch, D. J., A. Dolan, S. Donald, and H. K. Brauer. 1986. Complete DNA sequence of the short repeat region in the genome of herpes simplex virus type 1. Nucleic Acid Res. 14:1727-1745.

22. Gosowski, P. J., and D. M. Knipe. 1986. Transcriptional control of herpes virus gene expression: gene functions required for positive and negative control. Proc. Natl. Acad. Sci. USA 83:256-268.

23. O'Hare, P., and G. S. Hayward. 1987. Comparison of upstream sequence requirements for positive and negative regulation of herpes simplex virus immediateearly gene by three virus-encoded trans-acting factors. J. Virol. 61:190-199.

24. Clements, B. J., R. J. Watson, and N. M. Wilkie. 1977. Temporal regulation of herpes simplex virus type 1 transcription: location of transcripts on the viral genome.

25. Wagner, E. K. 1985. Individual HSV transcripts. p.45-104. In B. Roizman (ed.), The herpesviruses, vol. 3. Plenum Publishing Corp., New York.

26. Mavromara-Nazos. P., M. Ackermann, and B. Roizman. 1986. Construction and properties of a viable 
herpes simplex virus 1 recombinant lacking coding sequences of the $\alpha 47$ gene. J. Virol. 60:807-812.

27. Aprhys, Colette M. J., D. M. Ciufo, E. A. O'Neill, T. J. Kelly, and G. S. Hayward. 1989. Overlapping octamer and TAATGARAT motifs in the VF65response elements in herpes simplex virus immediateearly promoters represent independent binding sites for cellular nuclear factor III. J. Virol. 63:2798-2812.

28. Kristie, T. M., and P. A. Sharp. 1990. Interaction of the Oct-1 POU subdomains with specific DNA sequences and with the HSV $\alpha$-trans-activator protein. Genes Dev. $4: 2383-2396$

29. Deluca, N. A., and A. McCarthy, and P. A. Schaffer. 1985. Isolation and characterization of deletion mutants of herpes simplex virus type 1 in the gene encoding immediate-early regulatory protein ICP 4. J. Virol. 56:558-570.

30. Deluca, N. A., and P. A. Schaffer. 1988. Physical and functional domains of the herpes simplex virus transcriptional regulatory protein ICP4. J. Virol. $62: 732-743$.

31. Godowsiki, J. P., and Knipe, M. D. Transcriptional control of herpesvirus gene expression: Gene functions required for positive and negative regulation. Proc. Natl. Acad. Sci. 1986; 83:256-260.

32. Arsenakis, M., J. Hubenthal-Voss, G. CampadelliFiume, I. Pereira, and B. Roizman. 1986.

Construction and properties of a cell line constitutively expressing the herpes simplex virus glycoprotein B dependent on functional $\alpha 4$ protein synthesis. J. Virol. 60:674-682.

33. Deluca, N. A., and P. A. Schaffer. 1985. Activation of immediate-early, early, and late promoters by temperature sensitive and wild-type forms of herpes simplex virus type 1 protein ICP4. Mol. Cell. Biol. 5:1997-2008.

34. Gelmsn. I. H., and S. Silverstein. 1985. Identification of immediate early genes from herpes simplex virus that transactivate the virus thymidine kinase gene. Proc. Natl. Acad. Sci. USA 82:5262-5269.

35. Mavromara-Nazos, P., S. Silver, J. HubenthalVoss, J. C. Mcknight, and B. Roizman. 1986. Regulation of herpes simplex virus 1 genes: a gene sequence requirements for transient induction of indicator genes regulated by $\beta$ or late $(\gamma 2)$ promoters. Virology 149:152-164.

36. Shepard, A. A., A. N. Imbalzano, and N. A. Deluca. 1989. Separation of primary structural 
components conferring autoregulation, transactivation, and DNA-binding propertied to the herpes simplex virus transcriptional regulatory protein ICP4. J. Virol. 63:3714-3728.

37. Preston, C. M. 1979. Control of herpes simplex virus type 1 mRNA synthesis in cells infected with wild-type virus or temperature-sensitive mutant ts $\mathrm{K}$. J. Virol. $29: 275-284$.

38. Imbalzano, A. N., A. A. Shepard, and N. A. Deluca. 1990. Functional relevance of specific interactions between herpes simplex virus type 1 ICP 4 and sequences from the promoter regulatory domain of the viral thymidine kinase gene. J. Virol. 64:26202631 .

39. Sekulovich, R. E., K. Leary, and R. M. SandriGoldin. 1988. The herpes simplex virus type $1 \alpha$ protein ICP27 can act as a trans-repressor or a transactivator in combination with ICP4 and ICPO. J. Virol. $62: 4510-4522$.

40. Su, L., and D. M. Knipe. 1989. Herpes simplex virus protein ICP27 can inhibit or augment viral gene transactivation. Virology 170:496-504.

41. Rice, S. A., D. M. Knipe. 1990. Genetic evidence for two distinct transactivation functions of the herpes simplex virus $\alpha$ protein ICP 27.

42. McNahan, I., and P. A. Schaffer. 1990. The repressing and enhancing function of the herpes simplex virus regulatory protein ICP 27 map to C-terminal regions and are required to modulate viral gene expression very early in infection. J. Virol. 64:34713485 .

43. McCarthy AM, McMahan I, Schaffer PA. Herpes simplex virus type 1 ICP27 deletion mutants exhibit altered patterns of transcription and are DNA deficient. J Virol 1989;63:18-27

44. Smith, I. I., M. A. Hardwicke, and M. SandriGoldin. 1992. Evidence that the herpes simplex virus immediate early protein ICP 27 acts posttranscriptionally during infection to regulate gene expression. Virology 186:74-86

45. Cai, W., and P. A. Schaffer. 1991. A cellular function can enhance gene expression and plating efficiency of a mutant defective in the gene for ICP0, a transactivating protein of herpes simplex virus type 1. J. Virol. 65:4078-4090

46. Gelman, I. H., and S. Silverstein. 1986. Coordinate regulation of herpes simplex virus gene expression is mediated by the functional interaction of 
two immediate early gene products. J. Mol. Biol. $191: 395-409$.

47. Mavromara-Nazos. P., S. Silver, J. HubenthalVoss, J. L. C. Mcknight, and B. Roizman. 1986. Regulation of herpes simplex virus 1 gene: a gene sequence requirements for transient induction of indicator genes regulated by $\beta$ or late $(\gamma 2)$ promoters. Virology 149:152-164.

48. Sears, A. E., I. W. Holliburton, B. Meigner, S. Silver, and B. Roizman. 1985. Herpes simplex virus type 1 mutant deleted in the a22 gene: growth and gene expression in permissive and restrictive cells and establishment of latency in mice. J. Virol. 55:338-346.

49. Everett, R. D. 1984. A detailed analysis of an HSV-1 early promoter: sequences involved in trans-activation by viral immediate-early gene products are not earlygene specific. Nucleic Acids Res. 12:3037-3056.

50. Tedder, D. G., and I. I. Pizer. 1988. Role for DNAprotein interaction in activation of the herpes simplex virus glycoprotein D gene. J. Virol. 62:4661-4672

51. Wagner, E. K. 1985. Individual HSV transcripts: characterization of specific genes, p. 45-104. In B. New York.

52. Weir, J. P., and P. R. Narayanan. 1990. Expression of the herpes simplex virus type 1 glycoprotein $C$ gene requires sequences in the $5^{\prime}$ ' noncoding region of the gene. J. Virol. 64:445-449

53. Holland, I. E., Anderson, K. P., Shipman, C. and Wagner, E. K. 1980. Virology 101:10-24.

54. Cohen GH, Ponce de Leon $M$, Deggelmann $H$, Lawrence WC, Vernon SK, Eisenberg RJ. 1980.

Structural analysis of the capsid polypeptides of herpes simplex virus types 1 and 2. J. Virol; 34:521531 .

55. Costa, R. H., K. G. Draper, G. Devi-Rao, R. I. Thompson, and E. K. Wagner. 1985. Virus-induced modification of the host cell is required for expression of the bacterial chloramphenicol acetyltransferase gene controlled by a late herpes simplex virus promoter(VP5). J. Virol. 56:19-30.

56. Frind, R., K. G. Draper, and E. K. Wagner. 1981 . Uninfected cell RNA polymerase efficiently transcribes early but not late HSV-1 mRNA. Proc. Natl. Acad. Sci. USA $78: 6139-6143$.

57. Sekulovich, E. R., K. Leary, and R. M. SandriGoldin. 1988. The herpes simplex virus type $1 \alpha$ protein ICP27 can act as a trans-repressor or a transactivator of combination with ICP4 and ICPO. J. Virol. $62: 4510-4522$ 
58. Persson, R. K., S. Bacchetti, and J. R. Smiley. 1985. Cells that constitutively express the herpes simplex virus immediate-early protein ICP 4 allow efficient activation of viral delayed-early genes in trans. J. Virol. 54:414-421.

59. Birnboim, H. C., and J. Doly. 1979. A rapid alkaline extraction procedure for screening recombinant plasmid DNA. Nucleic Acids Res. 7:1513-1523

60. Dignam, J. D., R. M. Lebowitz, and R. G. Roeder. 1983. Accurate transcription initiation by RNA polymerase II in a soluble extract from isolated mammalian nuclei. Nucleic Acids Res. 11:1475-1489

61. Dretzen, G., M. Bellard. P, Sassone-Corsi. and P. Chambon. 1981. A reliable method for the recovery of DNA fragments from agarose and acrylamide gels. Annual Biochem. 112:295-298

62. Maniatis, T., J. Sambrook, and E. F. Fritsch. 1982. Molecular cloning: a laboratory manual. Cold Spring Harbor Laboratory, Cold Spring Harbor, N.Y.

63. Fried, M., and D. M. Crothers. 1981. Equlibria and kinetics of lac repressor operator interactions by polyacrylamide gel electrophoresis. Nucleic Acid Res. $9: 6505-6525$

64. Maxam. A. M., ansd W. Gilbert. 1980. Sequencing end labeled DNA with base-specific chemical cleavages.

Methods Enzy. mol. 65:499-559

65. Gorman, C. M., I. F. Moffat, and B. H. Howard. 1982. Recombinant genomes which express chloramphenicol acetyltransferase in mammalian cells. Mol. Cell. Biol. $2: 1044-1051$.

66. Nordeen, S. K., P. P. Green III, and D. M. Fowlkes. 1987. A rapid, sensitive and inexpensive assay for chloramphenicol acetyltransferase. DNA 6:173178

67. Everett, R. D. 1986. The products of herpes simplex virus type 1 (HSV-1) immediate-early genes 1, 2, and 3 can activate HSV-1 gene expression in trans. J. Gen Virol. $67: 2507-2513$.

68. Chen, S., I. Mills, P. Perry, S. Riddle, R. wobig, $\mathbf{R}$. Lown, $\mathbf{R}$. Millette. 1992. Transactivation of the major capsid protein gene of herpes simplex virus type 1 requires a cellular transcription factor. J. Virol. 66:4304-4314.

69. Nagata, K., R. A. Guggenheimer, and J. Hurwitz . 1983. Specific binding of a cellular DNA replication protein to the origin of replication of adenovirus DNA. Proc. Nat1. Acad. Sci. USA 80:6177-6181.

70. Santoro, C., N. Mermod. P, C. Andrew, and R. Tjian. 1988. A family of human CCAAT-box-binding proteins active in transcription and DNA replication: 
cloning and expression of multiple cDNAs. Nature (London) 334:218-224.

71. Mills, L. K., Y. Shi, and R. L. Millette. 1994. YY1 is the cellular factor shown previously to bind to regulatory regions of several Leaky-Late $(\beta \gamma, \gamma 1)$ genes of Herpes simplex virus type 1. J. Virol. 68:1234-1238.

72. Margolis, D. M., A. B. Rabson, S. E. Straus, and J. M. Ostrove. 1992. Transactivation of the HIV-1 LTR by HSV-1 immediate-early genes. Virology 186:788-791.

73. Davis, M. G., S. C. Kenney, J. Kamine, J. S. Pagano, and E. S. Huang. 1987. Immediate-early gene region of human cytomegalovirus transactivates the promoter of human immunodeficiency virus. Natl. Acad. SCi. USA 84:8642-8646.

74. Geng, Y., B. Chandran, S. F. Josephs, and C. wood. 1992. Identification and characterization of a human herpesvirus 6 gene segment that trans activates the human immunodeficiency virus type 1 promoter. 66:1546-1570.

75. Vlach, J., and P. M. Pitha. 1993. Differential contribution of herpes simplex virus type 1 gene products and cellular factors to the activation of human immunodeficiency virus type 1 provirus. J. Virol. $67: 4427-4431$.

76. Mosac, J. D., D. P. Bednarik, N. B. K. Raj, C. A. Rosen. J. G. Sodroski, W. A. Haseltine, G. S. Hayward, and P.M. Pitha. 1987. Activation of human immunodeficiency virus by herpes virus infection: identification of a region within the long terminal repeat that responds to a trans-acting factor encoded by herpes simplex virus 1. Proc. Natl. Acad. Sci. USA 84:7408-7412.

77. Kakkis, E., and K. Calame. 1987. A plasmacytomaspecific factor binds the c-myc promoter region. Proc. Nat1. Acad. Sci. USA 84:7031-7035.

78. Kakkis, E., K. J. Riggs, W. Gillesple, and $K$. Calame. 1989. A transcription repressor of c-myc. Nature (London) 339:718-721.

79. Riggs, K. J., S. Saleque, K. K. Wong, $\mathbf{K}$. $\mathbf{T}$. Merrell, J. S. Lee, Y. Shi, and K. Calame. YinYang 1 activates the c-myc promoter. 1993. Mol. Cell. Biol. 13: 7487-7495

80. Hahn, $\mathbf{s}$. 1992. The yin and the yang of mammalian transcription. Curr. Biol. 2:152-154

81. Park, $\mathbf{K}$. and $\mathbf{M}$. I. Atchison. 1991. Isolation of a candidate repressor/activator, NF-E1(YY1, $\delta)$, that binds to the immunoglobulin $\mathrm{k}^{\prime}$ enhancer and the immuno- 
globulin heavy chain $\mu \mathrm{E} 1$ site. Proc. Natl. Acad. Sci. 88:9804-9808.

82. Shi, Y., E. Seto, I. S. Chang, and T. Shenk. 1991. Transcriptional repression by YY1, a human GLIKruppel-related protein, and relief of repression by adenovirus ElA protein. Cell 67:377-388

83. Riggs, K. J., K. T. Merrell, G. Willson, and K. Calame. 1991. Common factor 1 is a transcriptional activator which binds in the c-myc promoter, the skeletal $\alpha$-actin promoter, and the immunoglobulin heavy-chain enhancer. Mol. Cell. Biol. 11:1765-1769.

84. Natesan, S., and M. Z. Gilman. 1993. DNA bending and orientation-dependent function of YYl in the c-fos promoter. Genes \& Development 7:2497-2509.

85. Seto, E., B. Lewis, and T. Shenk. 1993. Interaction between transcription factor Spl and YY1. Nature $365: 462-464$.

86. Perez-Martin, $J$. and $M$. Espinosa. 1993. Proteininduced bending as a transcriptional switch. Science 260:805-807.

87. Wang, I., J. D. Helmann, and S. C. Winans. 1992. The $A$. tumefaciens transcriptional activator OccR causes a bend at a target promoter, which is partially relaxed by a plant tumor metabolite. Cell 69:659-667.

88. Horikoshi, M., C. Bertuccioli, R. Takada, J. Wang, T. Yamamoto, and R. G. Roeder. 1992. Transcription factor TFIID induces DNA bending upon binding to the TATA element. Proc. Natl. Acad. Sci. 89:1060-1064.

89. Kerppola, T. K. and T. Curran. 1991. Fos-Jun hetero-dimers and Jun homodimers bend DNA in opposite orientations: Implications for transcription factor cooperativity. Cell. 66:317-326.

90. Reid, I. H., R. G. Gregg, O. Smithies, and B. H. Koller. 1990. Regulatory elements in the introns of the human HPRT gene are necessary for its expression in embryonic stem cells. Proc. Natl. Acad. Sci. USA $87: 4299-4303$.

91. Hurt, M. M., T. I. Bowman. and W. F. Marzluff. 1991. A common transcriptional activator is located in the coding region of two replication-dependent mouse histone genes. Mol. Cell. Biol. 11:2929-2936 